\title{
Classifying Cider Apple Germplasm Using Genetic Markers for Fruit Acidity
}

\author{
Shanthanu Krishna Kumar and Nathan Wojtyna \\ School of Integrative Plant Science, Horticulture Section, Cornell University, Ithaca, NY 14853 \\ Laura Dougherty and Kenong Xu \\ School of Integrative Plant Science, Horticulture Section, Cornell AgriTech, Geneva, NY 14456 \\ Gregory Peck \\ School of Integrative Plant Science, Horticulture Section, Cornell University, Ithaca, NY 14853
}

\begin{abstract}
AdDitional INDEX words. apple juice, hard cider, malic acid, Malus $\times$ domestica
ABstract. The organic acid concentration in apple (Malus $\times$ domestica) juice is a major component of hard cider flavor. The goal of this study was to determine if the malic acid markers, Ma1 and $Q 8$, could classify the titratable acidity concentration in cider apple accessions from the United States Department of Agriculture Malus germplasm collection into descriptive classifications. Our results indicate that for diploid genotypes, the Ma1 marker alone and the $M a 1$ and $Q 8$ markers analyzed together could be used to predict cider apple acidity $(P<0.0001)$. Alone, the $M a 1$ marker categorized acidity into low $\left(<2.4 \mathrm{~g} \cdot \mathrm{L}^{-1}\right)$, medium $\left(2.4-5.8 \mathrm{~g} \cdot \mathrm{L}^{-1}\right)$, and high $\left(>5.8 \mathrm{~g} \cdot \mathrm{L}^{-1}\right)$ groups. The combination of $M a 1$ and $Q 8$ markers provided more specificity, which would be useful for plant breeding applications. This work also identified a significant difference $(P=\mathbf{0 . 0 1 3 2})$ in acidity associated with ploidy. On average, the triploids accessions had $0.33 \mathrm{~g} \cdot \mathrm{L}^{-1}$ higher titratable acidity than the diploid accessions. Based on the results of this work, we propose a genetics-based classification system for cider apples with the acidity component defined by the Mal and Q8 markers.
\end{abstract}

Although fresh market apples comprise the majority of global apple (Malus $\times$ domestica) production, cider apples have been of particular interest recently because their higher acidity and tannin content (a group of polyphenols with bitterness and astringency) can potentially produce a hard cider with a depth of flavor similar to that of wine. Ciderspecific apples can have five-times to 10-times more tannins than dessert apples and a wide range of organic acid concentrations (perceived as sourness and often described as sharpness) (Thompson-Witrick et al., 2014). In the United States, there is currently more demand than supply for

Received for publication 13 Feb. 2021. Accepted for publication 23 Mar. 2021.

Published online 11 May 2021.

We thank Ian Merwin, Gayle Volk, and Thomas Chao for sharing their lists of cider apple accessions. David Zakalik is acknowledged for his work identifying heirloom accessions in the U.S. Department of Agriculture (USDA) Malus collection that were added to the cider apple accession list, as well as his many hours collecting and processing fruit for this study. Mike Brown conducted most of the juice titrations and $\mathrm{pH}$ measurements. Nicholas Howard provided critical information and advice regarding pedigree and ploidy level and, with Caroline Denancé, shared the MUNQ attribution numbers for the accessions used in our study. Thomas Chao and Benjamin Gutierrez helped us navigate the USDA Malus collection. We thank Lynn Johnson from the Cornell Statistical Consulting Unit, who provided statistical advice. This material is based on work that is supported by the National Institute of Food and Agriculture, U.S. Department of Agriculture, Hatch Funds (accession no. 1014042) and an Agriculture and Food Research Initiative grant (no. 2014-67013-21660), Cornell University's Atkinson Centre for Sustainability-Sustainable Biodiversity Fund, and Cornell University's Arthur Boller Research Fund. The Indian Council of Agricultural Research supported Krishna Kumar's training at Cornell under the Netaji Subhas International Fellowship.

G.P. is the corresponding author. E-mail: gmp32@cornell.edu.

This is an open access article distributed under the CC BY-NC-ND license (https://creativecommons.org/licenses/by-nc-nd/4.0/). cider-specific apple cultivars (Pashow, 2018). In response to this supply chain imbalance, cider-specific cultivars, mostly of European origin, are being planted throughout the country (Miles et al., 2020). However, there is limited information regarding the juice quality characteristics of these apple cultivars.

The emerging U.S. cider industry has adopted a method of classifying cider apples that was originally developed at the Long Ashton Research Station (LARS) near Bristol, UK, over a century ago (Barker and Ettle, 1910). The LARS system classifies apple cultivars into one of four categories, sweet, bittersweet, sharp, or bittersharp, based on tannin and titratable acidity (TA) concentrations. Tannins were originally measured using the Löwenthal permanganate titration method (Snyder, 1893). A tannic acid concentration of $2 \mathrm{~g} \cdot \mathrm{L}^{-1}$ is used to separate nonbitter from bitter apples. Acidity was, and still is, measured using an acid-base titration at a $\mathrm{pH}$ endpoint of 8.1. Apples with a malic acid equivalent concentration less than $4.5 \mathrm{~g} \cdot \mathrm{L}^{-1}$ are classified as sweet, and those with a malic acid equivalent concentration greater than $4.5 \mathrm{~g} \cdot \mathrm{L}^{-1}$ are classified as sharp. Although plant genetics and sensory science have progressed greatly since the early 20th century, the LARS system has remained unchanged.

A French classification system is used to divide cider apples into the following six categories (English translation in parenthesis): amère (bitter); douce amère (bittersweet); douce (sweet); acidulée (subacid); aigre (sharp); and aigre amère (bittersharp) (Institut Français Des Productions Cidricoles, 2009). The acidity component of the French cider apple classification method has three categories, douce, acidulée, and aigre. The douce category is defined as having less than $4.5 \mathrm{~g} \cdot \mathrm{L}^{-1} \mathrm{TA}$, which is the same threshold used by the LARS classification system. The acidulée category is defined as TA values between 
4.5 and $6.75 \mathrm{~g} \cdot \mathrm{L}^{-1} \mathrm{TA}$. The aigre category includes apples with greater than $6.75 \mathrm{~g} \cdot \mathrm{L}^{-1} \mathrm{TA}$.

A Spanish cider classification system has undergone changes more recently than the LARS classification system and now includes the following six technical groups: sweet $\left(<1.45 \mathrm{~g} \cdot \mathrm{L}^{-1}\right.$ tannic acid and $\left.<4.85 \mathrm{~g} \cdot \mathrm{L}^{-1} \mathrm{TA}\right)$; bittersweet $\left(>1.45 \mathrm{~g} \cdot \mathrm{L}^{-1}\right.$ tannic acid and $\left.<4.85 \mathrm{~g} \cdot \mathrm{L}^{-1} \mathrm{TA}\right)$; semi-acid $\left(<1.45 \mathrm{~g} \cdot \mathrm{L}^{-1}\right.$ tannic acid and 4.85-6.56 g. $\left.\mathrm{L}^{-1} \mathrm{TA}\right)$; semi-acid-bitter $\left(>1.45 \mathrm{~g} \cdot \mathrm{L}^{-1}\right.$ tannic acid and $\left.4.85-6.56 \mathrm{~g} \cdot \mathrm{L}^{-1} \mathrm{TA}\right)$; acid $\left(<1.45 \mathrm{~g} \cdot \mathrm{L}^{-1}\right.$ tannic acid and $\left.6.56 \mathrm{~g} \cdot \mathrm{L}^{-1} \mathrm{TA}\right)$; and acid-bitter $\left(>1.45 \mathrm{~g} \cdot \mathrm{L}^{-1}\right.$ tannic acid and $>6.56 \mathrm{~g} \cdot \mathrm{L}^{-1} \mathrm{TA}$ ) (Ministerio De Agricultura, Pesca y Alimentacion, 2003).

The major organic acid in mature apple fruit is malic $(\approx 90 \%$ to $\left.95 \%, 3-5 \mathrm{~g} \cdot \mathrm{L}^{-1}\right)$, followed by quinic $(\approx 4 \% ; 0.2-0.5$ $\left.\mathrm{mg} \cdot \mathrm{L}^{-1}\right)$, citric $\left(\approx 1.5 \% ; 0.05-0.07 \mathrm{mg} \cdot \mathrm{L}^{-1}\right)$, and trace amounts $\left(<0.05 \mathrm{mg} \cdot \mathrm{L}^{-1}\right)$ of ascorbic, shikimic, succinic formic, maleic, and tartaric acid (Wu et al., 2007; Zhang et al., 2010). The genetic underpinnings of apple acidity were first described in 1959, and subsequent studies have led to the identification and characterization of the malic acid (Ma) locus on linkage group 16 (Maliepaard et al., 1998; Nybom, 1959; Visser and Verhaegh, 1978; $\mathrm{Xu}$ et al., 2012; Yao et al., 2008). This locus has been reported to control $17 \%$ to $42.3 \%$ of the variation in acid concentration in apple fruit (Xu et al., 2012). The gene underlying $M a$, named $M a 1$, has been identified to encode an aluminum-activated malate transporter-like protein (Bai et al., 2012; Khan et al., 2013). A single nucleotide mutation from the guanine $(G)$ to adenine (A) at position 1455 in the coding sequence of $\mathrm{Mal}$ results in a premature stop codon that truncates 84 amino acids at the C-terminus, causing low acidity (Bai et al., 2012; Li et al., 2020). Therefore, the Mal allele, with "G" at position 1455 , is associated with high acid $(M a)$, and the $M a 1$ allele with "A" at position 1455 is associated with low acid ( $m a)$. This distinction defines the difference between the dominant $M a$ and recessive $m a$ alleles. However, the dominance of the Mal allele is incomplete, which was indicated by the wide range of TA values for the heterozygous Mama allele, suggesting that both additive and dominant effects of the Mal allele exist (Verma et al., 2019; Xu et al., 2012). Recently, it was found that in response to excess nitrate accumulation, the $M d B T 2$ protein modulated and downregulated the expression of $M d C I b H L H 1$ and $M d M Y B 73$, which regulate malate-related genes, thus reducing acidity in apples (Zhang et al., 2020).

Linkage group 8 also contains an important quantitative trait locus (QTL), named $\mathrm{Ma3}$, that regulates apple acidity (Kumar et al., 2013; Liebhard et al., 2003; Ma et al., 2015; Sun et al., 2015; Verma et al., 2019). Recently, the Ma3 locus has been shown to have an incomplete dominance effect on apple acidity (Rymenants et al., 2020). Jia et al. (2018) identified two natural variations in hierarchical epistatic genes, MdSAUR37 and $M d P P 2 C H$, that affect fruit acidity in the Ma3 region. To genotype the Ma3 locus, a sequence tagged site (STS) marker, named $Q 8$, was developed, which is physically located at $11.1 \mathrm{Mb}$ between genes MdPP2CH $(8.7 \mathrm{Mb})$ and MdSAUR37 $(11.6 \mathrm{Mb})$ on chromosome 8 in the GDDH13 apple reference genome (Daccord et al., 2017; Jia et al., 2018). Additionally, three more QTLs, Ma4, Ma5, and Ma6 located on chromosomes 6, 1, and 4 , respectively, were found to be relevant for fruit acidity levels (Ban and Xu, 2020; Rymenants et al., 2020). These QTLs appeared to explain more variation in the background of $M a M a$ and Mama with relatively high acidity levels $\left(>10 \mathrm{~g} \cdot \mathrm{L}^{-1}\right)(\mathrm{Ban}$ and $\mathrm{Xu}, 2020$ ).

Because of the major effects of Mal and Ma3 loci on fruit acidity levels less than $10 \mathrm{~g} \cdot \mathrm{L}^{-1}$, we hypothesized that they could be used to predict acidity in apples, thereby allowing for classification into acidity ranges that would aid cider apple breeding, cultivar selection, and cider production. The goal of this study was to develop a genetic system for classifying $M$. $\times$ domestica cider apple acidity using the Mal and $Q 8$ markers.

\section{Materials and Methods}

STUdy LOCATION AND ACCESSION SELECTION. Apples were harvested in 2017, 2018, and/or 2019 from the Malus germplasm collection maintained by the U.S. Department of Agriculture (USDA) National Plant Germplasm System in Geneva, NY (lat. $42^{\circ} 53^{\prime} 40.3^{\prime \prime} \mathrm{N}$, long. $77^{\circ} 00^{\prime} 23.8^{\prime \prime} \mathrm{W}$ ). We compiled a list of 330 M. $\times$ domestica cultivars within the Malus germplasm collection that are mentioned in historic European and American texts and/ or are currently being used for hard cider (Supplemental Fig. 1). Additional $M . \times$ domestica accessions were identified by searching the USDA Germplasm Resources Information Network (GRIN) Global database (USDA, 2020) for accessions with astringent, aromatic, and/or acidic fruit that were greater than $50 \mathrm{~g}$ at harvest. Trees that appeared unhealthy or had insufficient fruit for analyses were excluded. Ploidy data were obtained from a 20,000 single-nucleotide polymorphism (SNP) array as part of an ongoing collaborative apple pedigree reconstruction project (Denancé et al., 2020; Howard et al., 2018; Muranty et al., 2020). Accessions without associated ploidy data were removed from the dataset. These steps led to the selection of $217 \mathrm{M}$. $\times$ domestica accessions (Supplemental Table 1).

DNA EXTRACTION AND ACCESSION GENOTYPING. Young leaves of the selected accessions were collected between 2017 and 2019. Leaf tissue (15-20 mg) was ground for $1 \mathrm{~min}$ using a tissue lyser (TissueLyserII; Qiagen, Venio, the Netherlands). Samples were incubated for $1 \mathrm{~h}$ in a hexadecyltrimethylammonium bromide $(\mathrm{CTAB})$ extraction buffer containing polyvinylpyrrolidone (catalogue number BP431-500; Thermo Fisher Scientific, Waltham, MA) and $\beta$-mercaptoethanol (catalogue number BP176-100; Thermo Fisher Scientific) (Doyle and Doyle, 1987). A spectrophotometer (NanoDrop 1000; Thermo Fisher Scientific) was used for DNA quantification.

A cleaved amplified polymorphic sequence marker $\left(\mathrm{CAPS}_{1455}\right)$ targeting base 1455 in the open reading frame of the Mal gene was used to distinguish the SNP between the Mal alleles, as previously described (Bai et al., 2012). Briefly, polymerase chain reaction (PCR)-amplified products were digested overnight with BspHI (New England Bio Laboratories, Ipswich, $\mathrm{MA}$ ) in a $37^{\circ} \mathrm{C}$ water bath overnight. Digested products were visualized on a $1.5 \%$ agarose gel, and Mal genotypes were determined based on band patterning. The PCR program included 2 min at $98^{\circ} \mathrm{C}, 35$ cycles of $10 \mathrm{~s}$ at $98^{\circ} \mathrm{C}, 15 \mathrm{~s}$ at $55^{\circ} \mathrm{C}$, and $90 \mathrm{~s}$ at $72^{\circ} \mathrm{C}$, and then a final $5 \mathrm{~min}$ at $72^{\circ} \mathrm{C}$. The reactions were conducted in $20-\mu \mathrm{L}$ volumes containing $1 \times$ PrimeSTAR MAX DNA Polymerase (R045A; Takara/Clontech, Mountain View, CA), $0.5 \mathrm{~mm}$ of each primer, and $30 \mathrm{ng}$ of genomic DNA in a gradient thermal cycler (Mastercycler ${ }^{\mathbb{B}}$ EP; Eppendorf, Hamburg, Germany). Restriction digestion was performed for $12 \mathrm{~h}$ at $37^{\circ} \mathrm{C}$ in $20-\mu \mathrm{L}$ reactions that contained $10 \mu \mathrm{L}$ PCR products, 2 units of BspHI restriction enzyme (New England Biolabs, 
Ipswich, MA), and $1 \times$ NEBuffer 4 (New England Biolabs). After sample incubation, $7 \mu \mathrm{L}$ of sample and $3 \mu \mathrm{L}$ of loading dye were injected into each well of a $1.5 \%(\mathrm{w} / \mathrm{v})$ agarose gel. The samples were suspended in a 1-N Tris/Acetate/EDTA (TAE) buffer solution. After $1 \mathrm{~h}$ of electrophoresis, the gels were stained with ethidium bromide at a concentration of $2 \mu \mathrm{L}$ to 100 $\mathrm{mg}$ of gel. Then, the banding patterns in the gel were illuminated with a 110-V ultraviolet light transilluminator (Thermo Fisher Scientific). The banding patterns in the gel images were visually scored and the Mal alleles for each accession were recorded.

The $Q 8$ marker primer sequences were 5'-AAAAATTGAAACTTGTGGATCGTT-3' (forward primer) and 5'-AAATCAAAAGCATACCACCACA- $3^{\prime}$ (reverse primer). The marker was PCR-amplified using $1 \times$ OneTaqDNA Polymerase $(\mathrm{New}$ England BioLabs) with the following conditions: $2 \mathrm{~min}$ at $98^{\circ} \mathrm{C}$, 35 cycles of $30 \mathrm{~s}$ at $94{ }^{\circ} \mathrm{C}, 30 \mathrm{~s}$ at $54^{\circ} \mathrm{C}$, and $45 \mathrm{~s}$ at $68^{\circ} \mathrm{C}$. The PCR products were visualized on $1.5 \%$ agarose gel and scored for $Q 8$ genotypes.

Fruit SAMPLing AND PRoCessing PROCEdUREs. Of the $217 \mathrm{M}$. $\times$ domestica accessions, 32 accessions were collected for 3 years, 114 accessions were collected for 2 years, and 71 accessions were collected for 1 year (Supplemental Table 1). The biennial bearing habit of many of these accessions made fruit unavailable during every year. Fruit was sampled from mid-August to midNovember. Before harvest, two fruit per accession that were near the reported harvest date in GRIN-Global were field-tested in situ for maturity using the cortex starch pattern index (SPI) (Blanpied and Silsby, 1992). An iodine solution $(0.22 \% \mathrm{w} / \mathrm{v}$ iodine, $0.88 \% \mathrm{w} / \mathrm{v}$ potassium iodine) (EMD Millipore Corp., Billerica, MA) was applied to the stem-side of an equatorial crosssection of the apple. A visual rating of the stained cortex flesh (hypanthium and mesocarp) was conducted and recorded using a scale ranging from 1 to 8 , where $1=100 \%$ staining (no starch degradation) and $8=0 \%$ staining (complete starch degradation). As much as possible, fruit was harvested when they were rated to have a SPI of 6 or more.

Fifteen fruit were randomly harvested from different regions of the tree canopy while avoiding selecting two or more fruit from the same branch. The unique identifying plant introduction (PI) number given to each accession in the USDA-PGRU collection was recorded and used to track the fruit throughout the phenotyping process. After harvest, the 15 fruit were randomly divided into three groups of five apples to allow for three subsamples of five fruit per sampled accession (Evans et al., 2012). The fruit were stored at $4{ }^{\circ} \mathrm{C}$ in a commercial storage room under ambient atmospheric gases for 1 to 4 weeks before fruit processing analysis at the Cornell University Agricultural Experiment Station Research Orchards in Ithaca, NY.

The SPI was determined for all sample apples as described. The calyx half of each pooled subsample of five apples was milled and pressed in a juicer (model 280; Norwalk Juicers, Bentonville, AR). Juice from each subsample replication was stirred and aliquoted into $50-\mathrm{mL}$ tubes. All juice-extracting equipment was rinsed with water between samples to minimize cross-contamination. Juice samples were stored at $-80^{\circ} \mathrm{C}$ until titrations were performed.

Juice TITRATABle ACIDITy AND PH. Samples were thawed to room temperature and then vortexed for $10 \mathrm{~s}$. Juice TA and $\mathrm{pH}$ were measured with an automatic titrator (Unitrode $\mathrm{pH}$ meter, 778 sample processor, and 800 Dosino dosing device; Metrohm, Herisau, Switzerland). Juice acidity was measured by titrating a
5-mL juice aliquot against a standardized $0.1 \mathrm{~N} \mathrm{NaOH}$ solution to an endpoint of $\mathrm{pH} 8.1$ and expressed in grams per liter of malic acid equivalents.

Statistical analysis. Linear models were developed using Ma1, Q8, or both markers as predictor variables and TA as the response variable with RStudio (version 1.1.442; RStudio, Boston, MA). The linear models were used to predict $95 \%$ confidence intervals (CIs) with the Estimated Marginal Means data analysis package. The data were not transformed before analysis. $P \leq 0.05$ was considered statistically significant.

\section{Results}

Fruit maturity, titratable aCidity, AND PH. The SPI for the 217 evaluated accessions ranged from 5 to 8 (mean, 6.96; $\mathrm{SE} \pm 0.06$ ) (Supplemental Table 1). More than $85 \%$ of the accessions had an average SPI more than 6. The TA ranged from 1.09 to $11.53 \mathrm{~g} \cdot \mathrm{L}^{-1}$ (mean, $4.48 \pm 0.16 \mathrm{~g} \cdot \mathrm{L}^{-1}$ ) (Fig. 1A). The $\mathrm{pH}$ ranged from 2.3 to 5.1 (mean, $3.84 \pm 0.03$ ) (Fig. 1B). The sample population had $113(52 \%)$ accessions with TA less than the mean and 104 (48\%) accessions with TA greater than the mean. There were two peaks in the TA distribution, one in the lower range representing most of the accessions with very low acidity with a peak at $1.5 \mathrm{~g} \cdot \mathrm{L}^{-1}$, and the other between 4.6 and 6.6 $\mathrm{g} \cdot \mathrm{L}^{-1}$, suggesting a bimodal distribution for fruit TA within our sample population.

Allelic Demographics. Of the 217 genotyped accessions, $181(83 \%)$ were diploid accessions and $36(17 \%)$ were triploid accessions (Supplemental Table 1). For the Mal marker, 17 $(9 \%)$ of the diploid accessions were homozygous dominant (MaMa), 107 (59\%) were heterozygous (Mama), and 57 (32\%) were homozygous recessive (mama) (Table 1). For the $Q 8$ marker, which is a likely marker for the Ma3 gene, $129(71 \%)$ of the diploid accessions were homozygous dominant (Q8Q8), 48 $(27 \%)$ were heterozygous $(Q 8 q 8)$, and $4(2 \%)$ were homozygous recessive $(q 8 q 8)$. The most common genotype combinations were Mama-Q8Q8 (66 accessions; 37\%), mama-Q8Q8 (49 accessions; 27\%), and Mama-Q8q8 (37 accessions; 20\%) (Table 1). The other allelic combinations each represented less than $10 \%$ of the total sample population, including three MaMa$Q 8 q 8$ accessions, four Mama- $q 8 q 8$ accessions, and eight mama$Q 8 q 8$ accessions. There were no MaMa- $q 8 q 8$ or mama- $q 8 q 8$ combinations among the accessions.

Allele diversity was less robust for the triploid accessions. The mamama_Q8Q8Q8 combination comprised 39\% of our triploid samples, Mama-_Q8Q8Q8 comprised 28\% of our triploid samples, and Mama-_Q8q8- comprised 33\% of our triploid samples (Table 1). This was partly because of a smaller sample size $(\mathrm{N}=36)$ and the inability to identify the third allele in triploid heterozygous accessions.

Relationships Among THE GeNOTYPES AND PHENOTYPES. Ploidy significantly influenced the TA concentration $(P=0.0132)$, with diploid accessions having $0.33 \mathrm{~g} \cdot \mathrm{L}^{-1}$ lower TA than triploids (4.43 and $4.76 \mathrm{~g} \cdot \mathrm{L}^{-1}$, respectively) (Table 2). The $\mathrm{pH}$ was not significantly affected by the ploidy level. The interactions between $M a l$ and $Q 8$ and ploidy were not significant, indicating that ploidy is independent of the Mal and $Q 8$ allele composition. Because of ploidy being a significant factor for TA, diploid and triploid accessions were analyzed separately for each Mal and Q8 allelic combination using estimated marginal means analyses and CIs (Tables 3 and 4). 

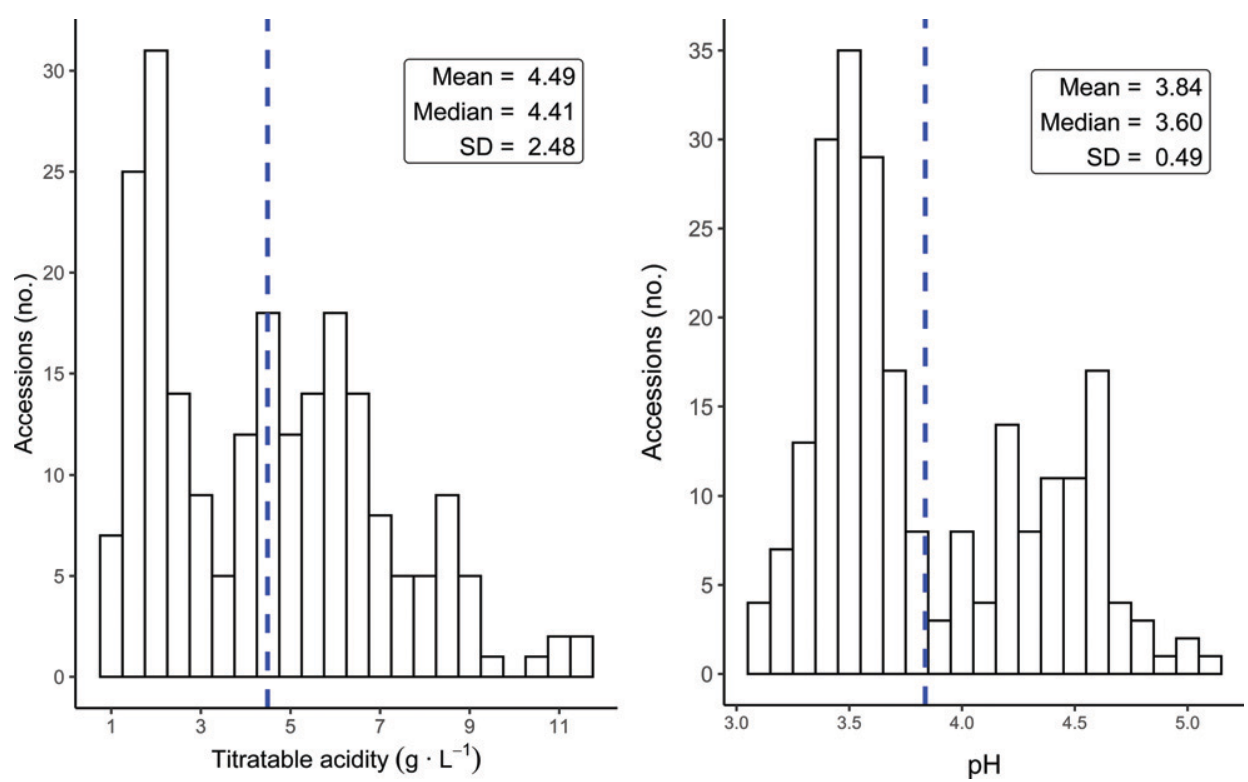

Fig. 1. The distribution of (A) titratable acidity and $(\mathbf{B}) \mathrm{pH}$ of cider apple accessions $(\mathrm{N}=217)$ harvested between 2017 and 2019, from the U.S. Department of Agriculture Malus germplasm collection in Geneva, NY.

Table 1. The number of cider apple accessions for each allelic combination of the Mal and $Q 8$ markers. Leaves from the sample population $(\mathrm{N}=217)$ were collected from the U.S. Department of Agriculture Malus germplasm collection in Geneva, NY.

\begin{tabular}{lcccccc}
\hline & \multicolumn{3}{c}{ Diploid accessions } & & \multicolumn{2}{c}{ Triploid accessions } \\
\cline { 2 - 4 } \cline { 6 - 7 } Allele & MaMa (no.) & Mama (no.) & Mama (no.) & & Allele $^{z}$ & (no.) \\
\hline Q8Q8 & 14 & 66 & 49 & & mamama_Q8Q8Q8 & 14 \\
Q8q8 & 3 & 37 & 8 & & Mama-_Q8Q8Q8 & 10 \\
$q 8 q 8$ & 0 & 4 & 0 & & Mama-_Q8q8- & 12 \\
\hline
\end{tabular}

z“__" = A missing allele in the heterozygous triploid accessions.

Table 2. Fixed effects from a simple linear model of the Mal and $Q 8$ markers and ploidy in a study of cider apple accessions $(\mathrm{N}=217)$ harvested between 2017 and 2019 from the U.S. Department of Agriculture Malus germplasm collection in Geneva, NY.

\begin{tabular}{|c|c|c|}
\hline & Titratable acidity & $\mathrm{pH}$ \\
\hline Fixed effects & \multicolumn{2}{|c|}{$P$ value } \\
\hline$\overline{M a 1}$ & $<0.0001$ & $<0.0001$ \\
\hline$Q 8$ & 0.5032 & 0.2361 \\
\hline$M a 1+Q 8$ & 0.0001 & $<0.0003$ \\
\hline Ploidy & 0.0132 & 0.1375 \\
\hline Mal $+Q 8 \times$ ploidy & 0.2275 & 0.6368 \\
\hline
\end{tabular}

For the diploids, the Mal marker had a significant effect on TA $(P<0.0001)$ and $\mathrm{pH}(P<0.0001)$, but the $Q 8$ marker did not show a significant effect for either TA or $\mathrm{pH}$ (Table 2). However, a detailed analysis of each $M a$ genotype group indicated that there was a significant difference between $Q 8 Q 8$ and $q 8 q 8$ within the Mama genotype, where all the $q 8 q 8$ accessions were found. This suggests that the insignificant effect of $Q 8$ on acidity of the 181 diploid accessions may have been related to the limited number of accessions $(\mathrm{N}=4)$ that possessed the recessive $q 8 q 8$ in our sample population (Tables 1 and 3, Fig. 2A). The analysis also revealed that for Mama and MaMa, the Q8Q8 genotype exhibited higher TA than $Q 8 q 8$, although that difference was not significant (Fig. 2A, Table 3). In the mama group, the difference in acidity between the $Q 8 Q 8$ and $Q 8 q 8$ genotypes were negligible (Fig. 2A, Table 3). Consequently, when the $M a 1$ and $Q 8$ markers were considered in combination, both TA $(P<0.0001)$ and $\mathrm{pH}$ $(P<0.0001)$ were correlated with the genotype (Table 2).

Classifying CIDER APPles by PHENOTYPE, GENOTYPE, AND REGION OF ORIGIN. The 217 cider apple accessions genotyped during this study were classified under the different existing regional classification systems based on acidity (Fig. 3). Using the 4.5 $\mathrm{g} \cdot \mathrm{L}^{-1}$ threshold from the LARS classification system, there was an approximately equal distribution of sweet $(52 \%)$ and sharp (48\%) cider apples. The French and Spanish classification systems showed a very similar spread of cider apple accessions, with $52 \%$ and $57 \%$ in the sweet category, $30 \%$ and $24 \%$ in the semi-acid category, and $18 \%$ and $19 \%$ in the acidic category, respectively (Fig. 3).

The $95 \%$ CI range (lower to upper CI) from the estimated marginal means test for each Mal allele alone and $M a 1$ and $Q 8$ allele combinations were used to develop classification thresholds for the diploid and triploid accessions separately (Table 3, Fig. 3). The Mal marker-based classification system discretely categorized the cider apple accessions with minimal overlap among the genotypes (Fig. 3). For the diploid accessions, the Mal marker could be classified into low $\left[\right.$ mama $\left.\left(<2.4 \mathrm{~g} \cdot \mathrm{L}^{-1}\right)\right]$, medium [Mama (2.4 to $\left.5.8 \mathrm{~g} \cdot \mathrm{L}^{-1}\right)$ ], and high $\left[\mathrm{MaMa}\left(>5.8 \mathrm{~g} \cdot \mathrm{L}^{-1}\right)\right]$ acidity levels. There were only two accessions that overlapped between the upper threshold for diploid Mama (5.78 $\mathrm{g} \cdot \mathrm{L}^{-1}$ ) and the lower threshold for MaMa $\left(5.60 \mathrm{~g} \cdot \mathrm{L}^{-1}\right)$. The diploid Mal and $Q 8$ allelic combinations categorized cider apples with multiple category overlaps; however, they provided more specificity. There was a significant difference between the Mama_q $8 q 8$ $\left(1.62-4.81 \mathrm{~g} \cdot \mathrm{L}^{-1}\right)$ and Mama_Q8Q8 $\left(5.5-6.8 \mathrm{~g} \cdot \mathrm{L}^{-1}\right)$ alleles.

The triploid accessions were classified into two categories solely using the Mal allele (mamama and Mama-). Homozygous dominant triploid Mal alleles were absent in the sample population. Using both the Mal and $Q 8$ alleles for the triploid accessions, there were three identified categories of $M a 1$ and $Q 8$ alleles (mamama_Q8Q8Q8, Mama-_Q8q8-, and Mama-_Q8Q8Q8). The triploid homozygous recessive mal alleles and homozygous 
Table 3. Estimated marginal means and the lower confidence intervals (LCIs) and upper confidence intervals (UCIs) for juice titratable acidity and $\mathrm{pH}$ for the Mal alleles alone and Mal $+Q 8$ allelic combinations among diploid $(\mathrm{N}=181)$ cider apple accessions harvested between 2017 and 2019 from the U.S. Department of Agriculture Malus germplasm collection in Geneva, NY. Some of the Mal and $Q 8$ allele combinations were omitted because of nonavailability of accessions with those genotypes.

\begin{tabular}{|c|c|c|c|c|c|c|c|}
\hline Allelic combinations & $\begin{array}{c}\text { Titratable acidity } \\
{\left[\text { mean } \pm \text { SE }\left(\mathrm{g} \cdot \mathrm{L}^{-1}\right)\right]}\end{array}$ & LCI $\left(g \cdot \mathrm{L}^{-1}\right)$ & $\mathrm{UCI}\left(\mathrm{g} \cdot \mathrm{L}^{-1}\right)$ & $\mathrm{pH}($ mean $\pm \mathrm{sE})$ & LCI & UCI & Accessions (no.) \\
\hline \multicolumn{8}{|l|}{ Mal allele alone } \\
\hline Mama & $1.92 \pm 0.226 \mathrm{c}^{\mathrm{z}}$ & 1.47 & 2.38 & $4.41 \pm 0.038 \mathrm{a}$ & 4.34 & 4.49 & 57 \\
\hline$M a M a$ & $6.42 \pm 0.415 \mathrm{a}$ & 5.60 & 7.24 & $3.53 \pm 0.069 \mathrm{c}$ & 3.39 & 3.67 & 17 \\
\hline \multicolumn{8}{|l|}{ Mal $+Q 8$ allele } \\
\hline$m a m a \_Q 8 q 8$ & $1.64 \pm 0.571 \mathrm{~d}$ & 0.51 & 2.77 & $4.53 \pm 0.102 \mathrm{a}$ & 4.32 & 4.73 & 8 \\
\hline$M a m a \_q 8 q 8$ & $3.21 \pm 0.808 \mathrm{~cd}$ & 1.62 & 4.81 & $3.90 \pm 0.145 \mathrm{~b}$ & 3.61 & 4.19 & 4 \\
\hline Mama_Q8q8 & $4.93 \pm 0.262 \mathrm{bc}$ & 4.42 & 5.45 & $3.64 \pm 0.047 \mathrm{~b}$ & 3.54 & 3.73 & 37 \\
\hline$M a M a \_Q 8 q 8$ & $5.24 \pm 0.933 \mathrm{abc}$ & 3.4 & 7.08 & $3.60 \pm 0.168 b$ & 3.27 & 3.93 & 3 \\
\hline Mama_Q8Q8 & $5.89 \pm 0.199 \mathrm{ab}$ & 5.5 & 6.28 & $3.54 \pm 0.035 \mathrm{~b}$ & 3.47 & 3.61 & 66 \\
\hline$M a M a \_Q 8 Q 8$ & $6.67 \pm 0.432 \mathrm{a}$ & 5.82 & 7.52 & $3.51 \pm 0.077 \mathrm{~b}$ & 3.36 & 3.67 & 14 \\
\hline
\end{tabular}

${ }^{\mathrm{z}}$ Means within columns followed by the same lowercase letter are not significantly different based on Tukey's means comparison at $\alpha=$ 0.05 and were analyzed separately for Mal alone and Mal + $Q 8$ allele combinations.

Table 4. The estimated marginal means and the lower confidence intervals (LCIs) and upper confidence intervals (UCIs) for juice titratable acidity and $\mathrm{pH}$ within each of the Mal allelic combinations among triploid cider apple accessions $(\mathrm{N}=36)$ harvested between 2017 and 2019 from the United States Department of Agriculture Malus germplasm collection in Geneva, NY. Some of the allelic combinations were omitted because of very low or no availability of accessions with those genotypes. The third allele in heterozygous triploid accessions was not identified; therefore, “-" represents an unknown allele.

\begin{tabular}{|c|c|c|c|c|c|c|c|}
\hline Allelic combinations & $\begin{array}{c}\text { Titratable acidity } \\
{\left[\text { mean } \pm \text { SE }\left(\mathrm{g} \cdot \mathrm{L}^{-1}\right)\right]}\end{array}$ & LCI $\left(g \cdot \mathrm{L}^{-1}\right)$ & $\mathrm{UCI}\left(\mathrm{g} \cdot \mathrm{L}^{-1}\right)$ & $\mathrm{pH}($ mean $\pm \mathrm{sE})$ & LCI & UCI & Accessions (no.) \\
\hline \multicolumn{8}{|l|}{$\overline{M a l}$ allele alone } \\
\hline Mamama & $2.13 \pm 0.508 b^{z}$ & 1.10 & 3.17 & $4.34 \pm 0.066 \mathrm{a}$ & 4.20 & 4.47 & 14 \\
\hline mamama_Q8Q8Q8 & $2.13 \pm 0.480 \mathrm{~b}$ & 1.16 & 3.11 & $4.34 \pm 0.062 \mathrm{a}$ & 4.21 & 4.46 & 14 \\
\hline$M a m a-\_Q 8 q 8-$ & $5.76 \pm 0.549 \mathrm{a}$ & 4.64 & 6.88 & $3.61 \pm 0.071 \mathrm{~b}$ & 3.46 & 3.75 & 12 \\
\hline
\end{tabular}

${ }^{\mathrm{z}}$ Means within columns followed by the same lowercase letter are not significantly different based on Tukey's means comparison at $\alpha=$ 0.05 and were analyzed separately for Mal alone and Mal $+Q 8$ allele combinations.
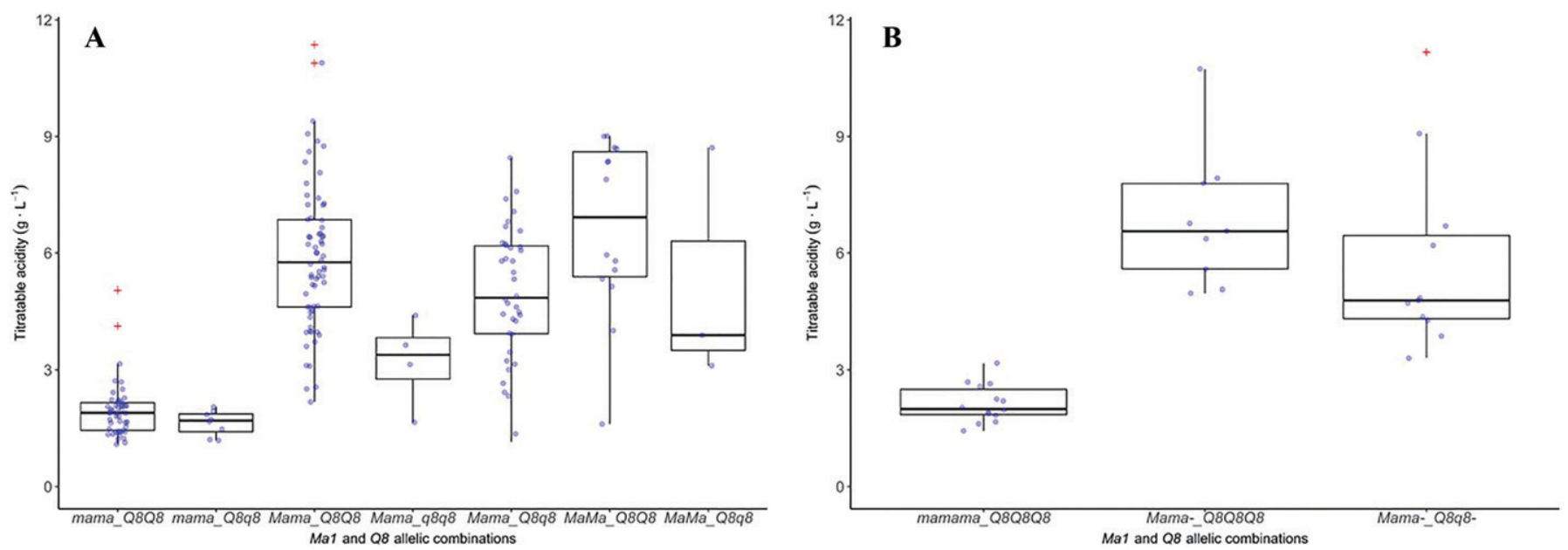

Fig. 2. The variation in titratable acidity for the $M a 1$ and $Q 8$ alleles among $(\mathbf{A})$ diploid accessions $(\mathrm{N}=181)$ and $(\mathbf{B})$ triploid accessions $(\mathrm{N}=36)$ between 2017 and 2019, from the U.S. Department of Agriculture Malus germplasm collection in Geneva, NY. The blue dots represent the estimated marginal means for each accession. The red plus signs represent outliers, as defined by the estimated marginal means test.

dominant $Q 8$ alleles (mamama_Q8Q8Q8) had an upper 95\% CI value of $3.11 \mathrm{~g} \cdot \mathrm{L}^{-1}$, which was $0.69 \mathrm{~g} \cdot \mathrm{L}^{-1}$ higher than their diploid counterpart (mama_Q8Q8). There were six accessions that overlapped in TA between the upper CI of the Mama-_Q8q8$\left(6.88 \mathrm{~g} \cdot \mathrm{L}^{-1}\right)$ and lower CI of $M a M a-\_Q 8 Q 8 Q 8\left(6.17 \mathrm{~g} \cdot \mathrm{L}^{-1}\right)$ allele combinations (Table 4, Supplemental Table 1). 


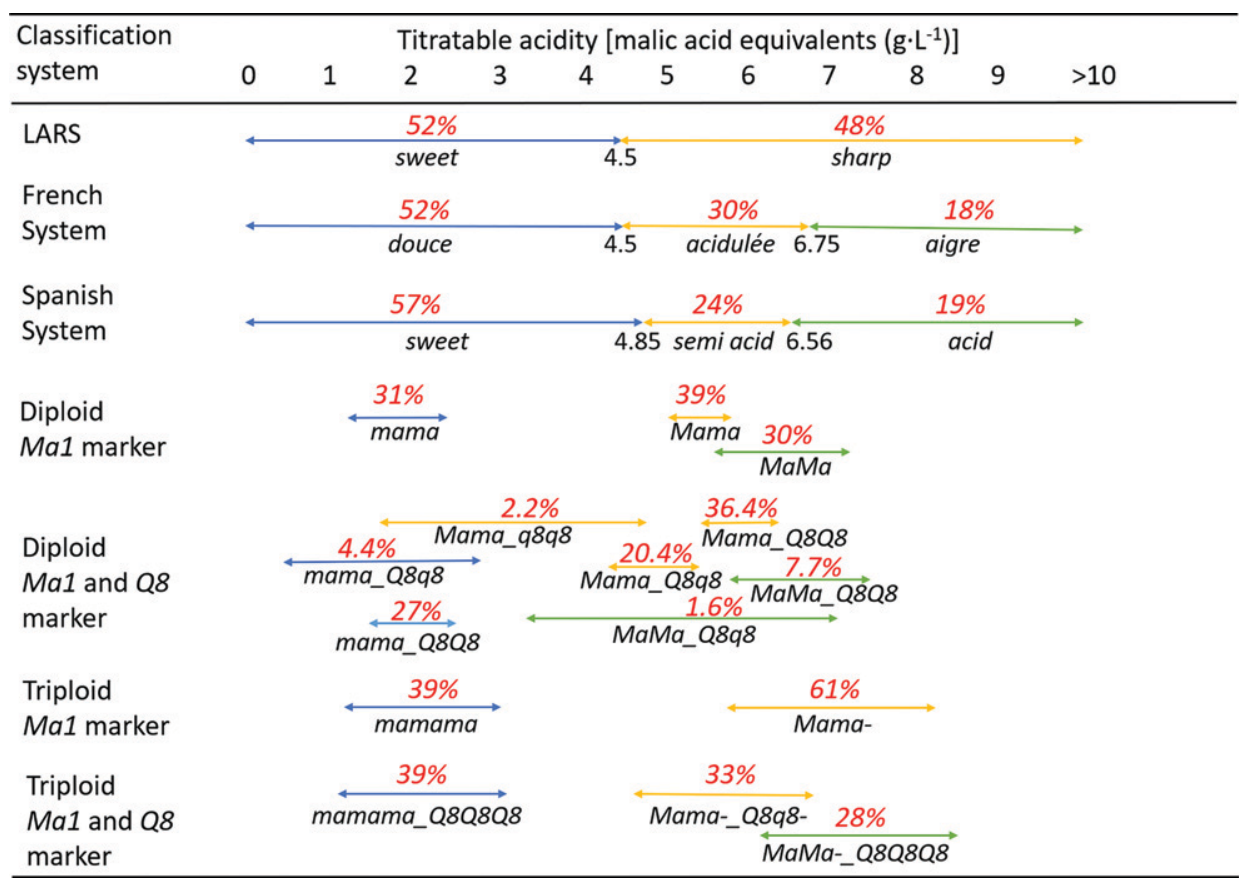

Fig. 3. Comparison of cider apple acidity classification systems for cider apple accessions $(\mathrm{N}=217)$ harvested between 2017 and 2019, from the U.S. Department of Agriculture Malus germplasm collection in Geneva, NY. For the Long Ashton Research Station (LARS), French, and Spanish classification systems, the percentages of accessions were calculated by titratable acidity. For the marker-based classification systems, the percentages of accessions were calculated according to the $M a 1$ and $Q 8$ allelic combinations for diploid $(\mathrm{N}=181)$ and triploid $(\mathrm{N}=$ 36) accessions. The third allele in heterozygous triploid accessions was not identified; therefore, "-" represents an unknown allele.

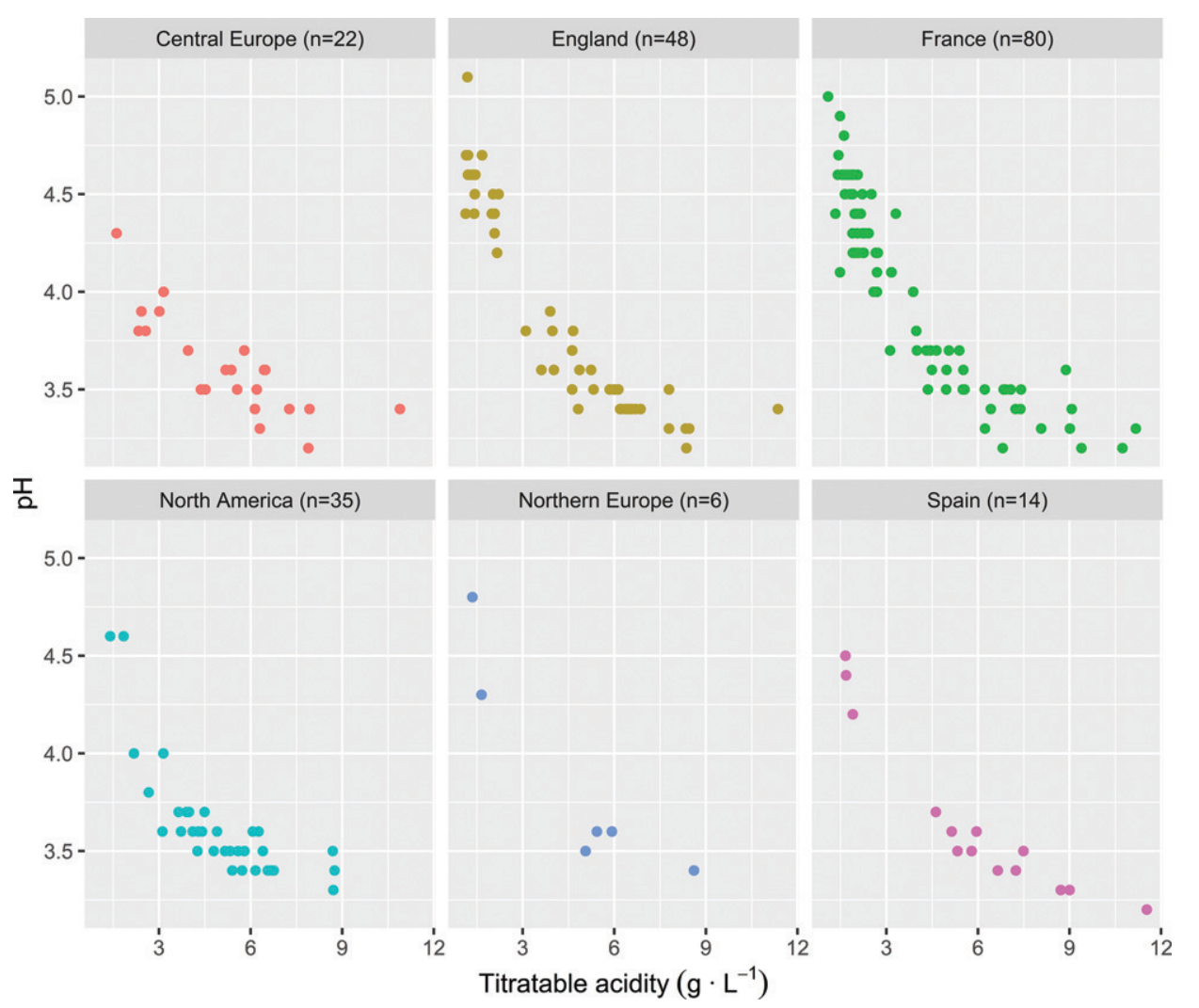

Fig. 4. The variations in titratable acidity and $\mathrm{pH}$ among cider apple accessions $(\mathrm{N}=205)$ harvested between 2017 and 2019, from the U.S. Department of Agriculture Malus germplasm collection in Geneva, NY, sorted according to their country or region of origin.
When the accessions were separated into broad geographic regions of origin, they exhibited a similar distribution, with accessions representing a TA range between 1.09 and $11.53 \mathrm{~g} \cdot \mathrm{L}^{-1}$ and pH between 2.3 and 5.1 (Fig. 4). Five accessions were removed because of unknown regions of origin and seven accessions were removed due to low representation ( $\leq 3$ accessions). Triploid accessions were represented in all major regions of origin. Among the 80 French accessions, there was a noticeable skew toward low to medium acid accessions, with 55 accessions with a LARS acidity threshold less than $4.5 \mathrm{~g} \cdot \mathrm{L}^{-1}$ and only 25 accessions with a LARS acidity threshold more than 4.5 $\mathrm{g} \cdot \mathrm{L}^{-1}$. Among the 55 accessions with low acid, 41 had the mama_Q8Q8 genotype. Within accessions that originated in England $(\mathrm{N}=48$ ), approximately one-quarter $(\mathrm{N}=13)$ also possessed the mama_Q8Q8 genotype. Twentytwo accessions originated in Central Europe; 19 of which possessed the heterozygous Mama alleles, indicating a strong skew toward medium acid accessions. All 14 Spanish accessions in the dataset had the homozygous dominant Q8Q8 allele and possessed all three types of the Mal alleles (MaMa, Mama, and mama). Three of the four accessions that possessed the homozygous recessive $q 8 q 8$ genotype originated in North America.

\section{Discussion}

MARKER-Based SYSTEM FOR CATEGORIZING CIDER APPLES. This study lays the groundwork for using the $M a 1$ and $Q 8(M a 3)$ acidity markers to categorize cider apple germplasm. Both the diploid and triploid Malus accessions had statistically significant correlations between the TA concentration and the Mal marker alone or Mal + Q8 markers analyzed together, but not the $Q 8$ marker alone. Based on the Mal marker and the estimated marginal mean model with a $95 \%$ CI, the diploid accessions could be grouped into ranges of low 
[mama $\left.\left(<2.4 \mathrm{~g} \cdot \mathrm{L}^{-1}\right)\right]$, medium [Mama $\left(2.4\right.$ to $\left.\left.5.8 \mathrm{~g} \cdot \mathrm{L}^{-1}\right)\right]$, and high $\left[\right.$ MaMa $\left.\left(>5.8 \mathrm{~g} \cdot \mathrm{L}^{-1}\right)\right]$ acidity. These three categories had negligible overlap in TA concentrations among accessions in our sample population. However, using only the Mal marker resulted in less precision than using both the Mal and $Q 8$ markers because of the larger range for each acidity category. Using both the Mal and $Q 8$ markers resulted in more specificity (smaller ranges), but also extensive overlap among the seven allelic combinations. For example, there were 16 accessions that overlapped between the upper CI of the heterozygous Mama allele and the lower CI of the homozygous dominant MaMa when the homozygous dominant $Q 8$ allele was constant between both $M a 1$ allele types. Therefore, the utility of using one or both markers would depend on the enduser's goals. Using both the Mal and $Q 8$ markers would be very beneficial to plant breeders in terms of precision breeding and making marker-assisted selections, whereas using the Mal marker alone would be useful for establishing a broad marker-based cider apple acidity classification system. The Mal marker is presently used in SNP arrays by breeders; however, there are no SNPs that are currently associated with the $Q 8$ marker.

Even though we analyzed a robust list of cider apple accessions, there were only four diploid and no triploid homozygous recessive $q 8 q 8$ genotypes. The lack of some allelic groups limited our ability to make conclusions about this allelic combination for identifying fruit acidity. It is unclear why there are very few cider apples with the homozygous recessive $q 8 q 8$ alleles; however, the reason may be related to human selection of apples with higher acid for cider production.

There were 128 accessions with a TA concentration for the Mama genotype group that spanned both sides of the LARS 4.5 $\mathrm{g} \cdot \mathrm{L}^{-1}$ threshold. Therefore, the Mal marker cannot be used as a predictor of the acidity component of the LARS cider apple classification system. With three acid categories, the French and Spanish systems were somewhat more closely matched to the Mal acidity markers. For example, the Mal marker categorized accessions with less than $2.4 \mathrm{~g} \cdot \mathrm{L}^{-1}$ as low acidity, and the French and Spanish systems classified apples with less than 4.5 and $4.85 \mathrm{~g} \cdot \mathrm{L}^{-1}$ as douce and sweet, respectively. Medium acidity ranged from 2.4 to $5.8 \mathrm{~g} \cdot \mathrm{L}^{-1}$ for the marker-based system, whereas the medium ranges were 4.5 to $6.75 \mathrm{~g} \cdot \mathrm{L}^{-1}$ and 4.85 to $6.56 \mathrm{~g} \cdot \mathrm{L}^{-1}$ for the French and Spanish systems, respectively. In general, there was a 1 - to 2 -g. $\mathrm{L}^{-1}$ difference among the French, Spanish, and Mal marker-based classification systems. Although apple classification systems are widely used by apple growers and cider producers, we have not found documentation that explains how the specific TA thresholds were chosen. The variations among the English, French, Spanish, and our proposed marker-based systems could be attributable to the perception of other flavor components in the apples, such as astringency, bitterness, and sweetness, which affect the way that acidity is perceived (Hampson et al., 2000). More sensory studies must be conducted to analyze the interdependency and perception thresholds among these important flavor components.

Similar to other studies that investigated apple fruit acidity genetics, our analyses indicate that the Mal gene is a reliable predictor $(P<0.0001)$ of TA (Bai et al., 2012; Khan et al., 2013). Therefore, our study adds to the body of literature indicating that the Mal gene largely determines apple acidity (Bai et al., 2015; Brown and Harvey, 1971; Kouassi et al., 2009; Nybom, 1959; Visser and Verhaegh, 1978; Xu et al., 2012). Although apple fruit acidity is affected by geographic, horticultural, and seasonal variations, the controlling genes are static and can assist breeders in making selections and/or crosses and apple growers in choosing cultivars to plant.

For the mama genotype, Xu et al. (2012) reported a mean TA concentration of $2.06 \mathrm{~g} \cdot \mathrm{L}^{-1}$, which is similar to the concentration of $1.92 \mathrm{~g} \cdot \mathrm{L}^{-1}$ obtained during our study. However, for the Mama and MaMa genotypes, Xu et al. (2012) reported mean TA values of 8.46 and $10.38 \mathrm{~g} \cdot \mathrm{L}^{-1}$, respectively, whereas our data indicate mean TA concentrations of 5.45 and $6.42 \mathrm{~g} \cdot \mathrm{L}^{-1}$, respectively. The discrepancies between these studies may be attributed to the sample populations and differences in maturity at harvest. The study by $\mathrm{Xu}$ et al. (2012) used two mapping populations containing a maternal 'Royal Gala' and two paternal M. sieversii parents, whereas the sample population in our dataset consisted almost entirely of $M$. $\times$ domestica cider cultivars. Duan et al. (2017) proposed that cultivated apples $M$. $\times$ domestica possess two distinct genetic regions of substantially reduced genetic diversity near the $\mathrm{Mal}$ gene in comparison with progenitor species $M$. sieversii. Therefore, increased genetic diversity in $M$. sieversii could have resulted in the higher TA for the Mama genotype in the Xu et al. (2012) study.

The Mal and $Q 8$ markers were the focus of our study because of their large genetic effect on fruit acidity that has been commonly detected in $M . \times$ domestica accessions with acidity levels lower than $10 \mathrm{~g} \cdot \mathrm{L}^{-1}$ TA. We propose that the Ma4, Ma5, and Ma6 markers should be used in future studies to further delineate cider apples into more precise classes, particularly those with acidity levels higher than $10 \mathrm{~g} \cdot \mathrm{L}^{-1}$ (Ban and Xu, 2020; Rymenants et al., 2020).

Because organic acids are metabolized during the ripening process, pH usually decreases (Ma et al., 2015). It should be noted that $\mathrm{pH}$ is in a logarithmic scale, and small differences can result in sensorially detectable perceptions of the overall flavor and taste of the fruit (Hampson et al., 2000). The low-acid mama genotypes had a $\mathrm{pH}$ range between 4 and 5, which is greater than the ideal $\mathrm{pH}$ range (3.2-3.8) for microbial control during cider fermentation (Kosseva et al., 2016). Higher $\mathrm{pH}(>3.8)$ could result in microbial contamination and the development of off flavors during cider fermentation. The $\mathrm{pH}$ values of diploid and triploid accessions are presented in Supplemental Fig. 2A and B.

Within and Among Year variability. Apple fruit acidity can be affected by within year (for example, harvest maturity and fruit location within the canopy) and year-to-year variations (for example, environmental conditions, crop load, and other biotic factors such as disease pressure) (Brown and Harvey, 1971). The variation in TA has been found to be dependent on cultivar and year more so than horticultural practices in the orchard (Bourvellec et al., 2015). Multiple years of acidity data collection for many of the accessions in our study minimized those effects. Additionally, fruit from different parts of the tree were mixed to obtain a representative sample. Furthermore, to reduce variability attributable to the ripening stage, all accessions in this study were harvested at a similar maturity, as measured using the SPI.

Previous studies examining the relationship between the Mal gene and TA evaluated the fruit at a mean SPI between 4 and 6 (Bai et al., 2012, 2015; Xu et al., 2012). However, the current study was focused on apple accessions for the hard cider industry; therefore, the goal was to test the fruit when the SPI was between 6 and 8 , a later stage in the maturity process. This late-stage timing was unique to this study and helped to gain a cider-specific focus on developing a genetic marker-based 
classification system for cider apples. Because TA fluctuates because of biotic and abiotic factors, a marker-based system provides a general range of how much acidity to expect; however, exact concentrations vary based on the aforementioned factors.

DIPLOID AND TRIPLOID ACCESSIONS. This study is one of the first to elucidate a significant difference in acidity concentrations in cider apples attributable to ploidy. On average, the diploid accessions had a TA concentration $0.33 \mathrm{~g} \cdot \mathrm{L}^{-1}$ less than that of triploid accessions, despite the lack of the dominant MaMaMa triploid genotype in our sample population. Therefore, the mean triploid acidity values were skewed toward the heterozygous and homozygous recessive Mal genotypes. This study corroborates the evidence from other fruit crops, such as citrus (Citrus sp.) and blueberry (Vaccinium sp.), that ploidy increases acidity levels (Ahmed et al., 2020; Mengist et al., 2020). The effect of ploidy on increasing acidity levels in cider apples could be attributable to the quantitative and additive natures of acid biosynthesis controlled by the major Mal gene (Brown and Harvey, 1971). Therefore, more copies of the dominant $\mathrm{Mal}$ allele would increase acidity concentrations.

Evaluated GERMPLASM. The USDA Malus germplasm collection contains the world's largest and most diverse catalog of $\mathrm{Ma}$ lus accessions, including a large collection of European and historic American cider apple cultivars, which was ideal for our analyses (Volk and Henk, 2016). The European cider cultivars in our study also included recently acquired traditional Spanish cider cultivars and traditional English and French bittersweet and bittersharp cultivars (Supplemental Table 1). A limitation to our study was that the USDA Malus germplasm collection consists of a single tree per accession and, thus, no field replication. Nonetheless, the sheer diversity of the collection has often been used to study the genetics of other important crop traits, such as dihydrochalcone content, volatile profiles, and anthocyanin production (Gutierrez et al., 2018; Sugimoto et al., 2015). Additionally, the geographically and genetically diverse accessions used for our study captured wide ranges of juice TA and $\mathrm{pH}$ that allowed us to identify potential genetic signatures to categorize cider apple genotypes. This diversity was further exploited to analyze accessions according to their country or region of origin.

Every country or region of origin had representative samples of low, medium, and high TA. There were some interesting trends observed during the analyses of acidity and region of origin. For example, 41 of the 80 analyzed French accessions possessed the homozygous recessive mama alleles and homozygous dominant Q8Q8 alleles, indicating a strong selection preference for low-acid accessions. The dominant $Q 8 Q 8$ allele was observed in all the Spanish accessions, indicating that this genotype could be fixed in most Spanish accessions. Future pedigree and genetic linkage studies will uncover the history, movement, and introgression of progenitor species and lineages among the cider apple cultivars.

FUTURE CIDER APPLE CLASSIFICATION RECOMMENDATIONS. This is the first study to use a marker-based classification system to identify cider apples. Although we concluded that the Mal and $Q 8$ markers could usefully segregate accessions in our sample pool, more germplasm must be evaluated to encompasses a wider range of allelic variability, particularly for triploids and accessions with the recessive $q 8$ alleles. Identification of additional acidity genes in apples would also help to account for more variability. Furthermore, sensory analyses would help to understand the thresholds for the human perception of acidity at different TA concentrations, as well as elucidate how other factors, such as sugar and polyphenol content, could affect the perception of acid in apples and cider (Hampson et al., 2000; Rymenants et al., 2020). Finally, adding genetic markers for sugar and polyphenol content would create a robust suite of markers for plant breeders, horticulturists, and commercial cider producers to use to rapidly identify potential cider apple cultivars in germplasm collections and breeding populations.

\section{Literature Cited}

Ahmed, D., J.C. Evrard, P. Ollitrault, and Y. Froelicher. 2020. The effect of cross direction and ploidy level on phenotypic variation of reciprocal diploid and triploid mandarin hybrids. Tree Genet. Genomes 16(1):1-16, doi: 10.1007/s11295-020-1417-7.

Bai, Y., L. Dougherty, L. Cheng, G.Y. Zhong, and K. Xu. 2015. Uncovering co-expression gene network modules regulating fruit acidity in diverse apples. BMC Genomics 16(1):1-16, doi: 10.1186/ s12864-015-1816-6.

Bai, Y., L. Dougherty, M. Li, G. Fazio, L. Cheng, and K. Xu. 2012. A natural mutation-led truncation in one of the two aluminum-activated malate transporter-like genes at the $M a$ locus is associated with low fruit acidity in apple. Mol. Genet. Genomics 287(8):663-678, doi: 10.1007/s00438-012-0707-7.

Ban, S. and K. Xu. 2020. Identification of two QTLs associated with high fruit acidity in apple using pooled genome sequencing analysis. Hort. Res. 7(1):1-14, doi: 10.1038/s41438-020-00393-y.

Barker, B.T.P. and J. Ettle. 1910. Report on the work of the National Fruit and Cider Institute 1903 10. 20 Dec. 2020. <https://www. biodiversitylibrary.org/item/76402\#page/9/mode/1up $>$.

Blanpied, G.D. and K. Silsby. 1992. Prediction of harvest date windows for apples. Cornell Coop. Ext. Info. Bul. 221. 20 Dec. 2020. $<$ https://ecommons.cornell.edu/bitstream/handle/1813/3299/Predicting $\% 20$ Harvest $\% 20$ Date $\% 20$ Window $\% 20$ for $\% 20$ Apples.pdf?sequence= 2\&isAllowed $=\mathrm{y}>$.

Bourvellec, C.L., S. Bureau, C.M.G.C. Renard, D. Plenet, H. Gautier, L. Touloumet, T. Girard, and S. Simon. 2015. Cultivar and year rather than agricultural practices affect primary and secondary metabolites in apple fruit. PLoS One 10(11):e0141916, doi: 10.1371/journal. pone.0141916.

Brown, A.G. and D.M. Harvey. 1971. The nature and inheritance of sweetness and acidity in the cultivated apple. Euphytica 20(1):68-80, doi: 10.1007/BF00146776.

Daccord, N., J.M. Celton, G. Linsmith, C. Becker, N. Choisne, E. Schijlen, H. Van de Geest, L. Bianco, D. Micheletti, R. Velasco, and E. Di Pierro. 2017. High-quality de novo assembly of the apple genome and methylome dynamics of early fruit development. Nat. Genet. 49(7):1099-1106, doi: 10.1038/ng.3886.

Denancé, C., H. Muranty, and C. Durel. 2020. MUNQ - Malus UNiQue genotype code for grouping apple accessions corresponding to a unique genotypic profile. Portail Data INRAE 20(1): doi: 10.15454/HKGMAS.

Doyle, J.J. and J.L. Doyle. 1987. A rapid DNA isolation procedure for small quantities of fresh leaf tissue. Phytochem. Bul. 19(1):11-15. $<$ https://webpages.uncc.edu/ jweller2/pages/BINF8350f2011/ BINF8350_Readings/Doyle_plantDNAextractCTAB_1987. pdf $>$.

Duan, N., Y. Bai, H. Sun, N. Wang, Y. Ma, M. Li, X. Wang, C. Jiao, N. Legall, L. Mao, S. Wan, K. Wang, T. He, S. Feng, Z. Zhang, Z. Mao, X. Shen, X. Chen, Y. Jiang, S. Wu, C. Yin, S. Ge, L. Yang, S. Jiang, H. Xu, J. Liu, D. Wang, C. Qu, Y. Wang, W. Zuo, L. Xiang, C. Liu, D. Zhang, Y. Gao, Y. Xu, K. Xu, T. Chao, G. Fazio, H. Shu, G.Y. Zhong, L. Cheng, Z. Fei, and X. Chen. 2017. Genome re-sequencing reveals the history of apple and supports a two-stage model for fruit enlargement. Nat. Commun. 8(1):1-11, doi: 10.1038/ s41467-017-00336-7.

Evans, K., Y. Guan, J. Luby, M. Clark, C. Schmitz, S. Brown, B. Orcheski, C. Peace, E. van de Weg, and A. Iezzoni. 2012. Large-scale standardized phenotyping of apple in RosBREED. Acta Hort. 945: 233-238, doi: 10.17660/ActaHortic.2012.945.31. 
Gutierrez, B.L., G.Y. Zhong, and S.K. Brown. 2018. Genetic diversity of dihydrochalcone content in Malus germplasm. Genet. Resources Crop Evol. 65(5):1485-1502, doi: 1007/s10722-018-0632-7.

Hampson, C.R., H.A. Quamme, J.W. Hall, R.A. MacDonald, M.C. King, and M.A. Cliff. 2000. Sensory evaluation as a selection tool in apple breeding. Euphytica 111(2):79-90, doi: 10.1023/A:1003769304778.

Howard, N.P., D.C. Albach, and J.J. Luby. 2018. The identification of apple pedigree information on a large diverse set of apple germplasm and its application in apple breeding using new genetic tools. 18th Intl. Conf. Organic Fruit-Growing, Hohenheim, Germany. 9:88-91 (Abstr.). Institut Français Des Productions Cidricoles. 2009. Pomme a cidre les variétés: Présentation des caractéristiques des principales variétés cidricoles. 20 Dec. 2020. <http://www.ifpc.eu/fileadmin/users/ifpc/ infos_techniques/Varietes_cidricoles.pdf $>$.

Jia, D., F. Shen, Y. Wang, T. Wu, X. Xu, X. Zhang, and Z. Han. 2018. Apple fruit acidity is genetically diversified by natural variations in three hierarchical epistatic genes: MdSAUR37, MdPP2CH and MdALMTII. Hort. Plant J. 95(3):427-443, doi: 10.1111/tpj.13957.

Khan, S.A., J. Beekwilder, J.G. Schaart, R. Mumm, J.M. Soriano, E. Jacobsen, and H.J. Schouten. 2013. Differences in acidity of apples are probably mainly caused by a malic acid transporter gene on LG16. Tree Genet. Genomes 9(2):475-487, doi: 10.1007/s11295-012-0571-y.

Kouassi, A.B., C.E. Durel, F. Costa, S. Tartarini, E. van de Weg, K. Evans, F. Fernandez-Fernandez, C. Govan, A. Boudichevskaja, F. Dunemann, A. Antofie, M. Lateur, M. Stankiewicz-Kosyl, A. Soska, K. Tomala, M. Lewandowski, K. Rutkovski, E. Zurawicz, W. Guerra, and F. Laurens. 2009. Estimation of genetic parameters and prediction of breeding values for apple fruit-quality traits using pedigreed plant material in Europe. Tree Genet. Genomes 5(4):659672, doi: 10.1007/s11295-009-0217-x.

Kosseva, M.R., V.K. Joshi, and P.S. Panesar. 2016. Science and technology of fruit wine production. 1st ed. Academic Press doi: 10.1016/B978-0-12-800850-8.00001-6.

Kumar, S., D.J. Garrick, M.C. Bink, C. Whitworth, D. Chagné, and R.K. Volz. 2013. Novel genomic approaches unravel genetic architecture of complex traits in apple. BMC Genomics 14(1):1-13, doi: 10.1186/1471-2164-14-393.

Li, C., L. Dougherty, A.E. Coluccio, D. Meng, I. El-Sharkawy, E. Borejsza-Wysocka, D. Liang, M.A. Pineros, K. Xu, and L. Cheng. 2020. Apple ALMT9 requires a conserved C-terminal domain for malate transport underlying fruit acidity. Plant Physiol. 182(2):9921006, doi: 10.1104/pp.19.01300.

Liebhard, R., M. Kellerhals, W. Pfammatter, M. Jertmini, and C. Gessler. 2003. Mapping quantitative physiological traits in apple (Malus $\times$ domestica Borkh.). Plant Mol. Biol. 52(3):511-526, doi: 10.1023/ A: 1024886500979 .

Ma, B., S. Zhao, B. Wu, D. Wang, Q. Peng, A. Owiti, T. Fang, L. Liao, C. Ogutu, S.S. Korban, S. Li, and Y. Han. 2015. Construction of a high-density linkage map and its application in the identification of QTLs for soluble sugar and organic acid components in apple. Tree Genet. Genomes 12(1):1, doi: 10.1007/s11295-015-0959-6.

Maliepaard, C., F.H. Alston, G. Van Arkel, L.M. Brown, E. Chevreau, F. Dunemann, K.M. Evans, S. Gardiner, P. Guilford, A.W. Van Heusden, and J.O. Janse. 1998. Aligning male and female linkage maps of apple (Malus pumila Mill.) using multi-allelic markers. Theor. Appl. Genet. 97(1-2):60-73, doi: 10.1007/s001220050867.

Mengist, M.F., M.H. Grace, J. Xiong, C.D. Kay, N. Bassil, K. Hummer, M.G. Ferruzzi, M.A. Lila, and M. Iorizzo. 2020. Diversity in metabolites and fruit quality traits in blueberry enables ploidy and species differentiation and establishes a strategy for future genetic studies. Front. Plant Sci. 11:370, doi: 10.3389/fpls.2020.00370.

Miles, C.A., T.R. Alexander, G. Peck, S.P. Galinato, C. Gottschalk, and S. van Nocker. 2020. Growing apples for hard cider production in the United States - Trends and research opportunities. HortTechnology 30(2):148-155, doi: 10.21273/HORTTECH04488-19.
Ministerio De Agricultura Pesca y Alimentacion. 2003. I. Disposiciones generals. 20 Dec. 2020. <https://www.boe.es/eli/es/rd/2003/03/28/376>. Muranty, H., C. Denancé, L. Feugey, J.L. Crépin, Y. Barbier, S. Tartarini, M. Ordidge, M. Troggio, M. Lateur, H. Nybom, and F. Paprstein. 2020. Using whole-genome SNP data to reconstruct a large multi-generation pedigree in apple germplasm. BMC Plant Biol. 20 (1):1-18, doi: 10.1186/s12870-019-2171-6.

Nybom, N. 1959. On the inheritance of acidity in cultivated apples. Hereditas 45(2-3):332-350, doi: 10.1111/j.1601-5223.1959.tb03056.x.

Pashow, L. 2018. Hard cider supply chain analysis. 20 Dec. 2020. $<$ https://harvestny.cce.cornell.edu/uploads/doc_48.pdf $>$.

Rymenants, M., E. van de Weg, A. Auwerkerken, I. De Wit, A. Czech, B. Nijland, H. Heuven, N. De Storme, and W. Keulemans. 2020. Detection of QTL for apple fruit acidity and sweetness using sensorial evaluation in multiple pedigreed full-sib families. Tree Genet. Genomes 16(5):1-17, doi: 10.1007/s11295-020-01466-8.

Snyder, H. 1893. Notes on Löwenthal's method for the determination of tannin. J. Amer. Chem. Soc. 15(10):560-563, doi: 10.1021/ja02120a004.

Sugimoto, N., P. Forsline, and R. Beaudry. 2015. Volatile profiles of members of the USDA Geneva Malus core collection: Utility in evaluation of a hypothesized biosynthetic pathway for esters derived from 2-methylbutanoate and 2-methylbutan-1-ol. J. Amer. Chem. Soc. 63(7):2106-2116, doi: 10.1021/jf505523m.

Sun, R., Y. Chang, F. Yang, Y. Wang, H. Li, Y. Zhao, D. Chen, T. Wu, X. Zhang, and Z. Han. 2015. A dense SNP genetic map constructed using restriction site-associated DNA sequencing enables detection of QTLs controlling apple fruit quality. BMC Genomics 16 (1):1-15, doi: 10.1186/s12864-015-1946-X.

Thompson-Witrick, K.A., K.M. Goodrich, A.P. Neilson, E.K. Hurley, G.M. Peck, and A.C. Stewart. 2014. Characterization of the polyphenol composition of 20 cultivars of cider, processing, and dessert apples (Malus $\times$ domestica Borkh.) grown in Virginia. J. Agr. Food Chem. 62(41):10181-10191, doi: 10.1021/jf503379t.

U.S. Department of Agriculture. 2020. Genetic Resource Information Network. 20 Dec. 2020. <https://www.grin-global.org/>

Verma, S., K. Evans, Y. Guan, J.J. Luby, U.R. Rosyara, N.P. Howard, N. Bassil, M.C.A.M. Bink, W.E. van de Weg, and C.P. Peace. 2019. Two large-effect QTLs, $M a$ and Ma3, determine genetic potential for acidity in apple fruit: Breeding insights from a multi-family study. Tree Genet. Genomes 15(2):1-17, doi: 10.1007/s11295-019-1324-y.

Visser, T. and J.J. Verhaegh. 1978. Inheritance and selection of some fruit characters of apple. II. The relation between leaf and fruit $\mathrm{pH}$ as a basis for preselection. Euphytica 27(3):761-765, doi: 10.1007/BF00023712.

Volk, G.M. and A.D. Henk. 2016. Historic American apple cultivars: Identification and availability. J. Amer. Soc. Hort. Sci. 141(3):292301, doi: 10.21273/JASHS.141.3.292.

Wu, J., H. Gao, L. Zhao, X. Liao, F. Chen, Z. Wang, and X. Hu. 2007. Chemical compositional characterization of some apple cultivars. Food Chem. 103(1):88-93, doi: 10.1016/j.foodchem.2006.07.030.

$\mathrm{Xu}, \mathrm{K} ., \mathrm{A}$. Wang, and S. Brown. 2012. Genetic characterization of the $\mathrm{Ma}$ locus with $\mathrm{pH}$ and titratable acidity in apple. Mol. Breed. 30(2): 899-912, doi: 10.1007/s11032-011-9674-7.

Yao, Y., H. Zhai, L. Zhao, K. Yi, Z. Liu, and Y. Song. 2008. Analysis of the apple fruit acid/low-acid trait by SSR markers. Front. Agr. China 2(4):463-466, doi: 10.1007/s11703-008-0069-4.

Zhang, Q.Y., K.D. Gu, J.H. Wang, J.Q. Yu, X.F. Wang, S. Zhang, C.X. You, D.G. Hu, and Y.J. Hao. 2020. BTB-BACK-TAZ domain protein MdBT2-mediated MdMYB73 ubiquitination negatively regulates malate accumulation and vacuolar acidification in apple. Hort. Res. 7(1):1-12, doi: 10.1038/s41438-020-00384-z.

Zhang, Y., P. Li, and L. Cheng. 2010. Developmental changes of carbohydrates, organic acids, amino acids, and phenolic compounds in 'Honeycrisp' apple flesh. Food Chem. 123(4):1013-1018, doi: 10.1016/j.foodchem.2010.05.053. 

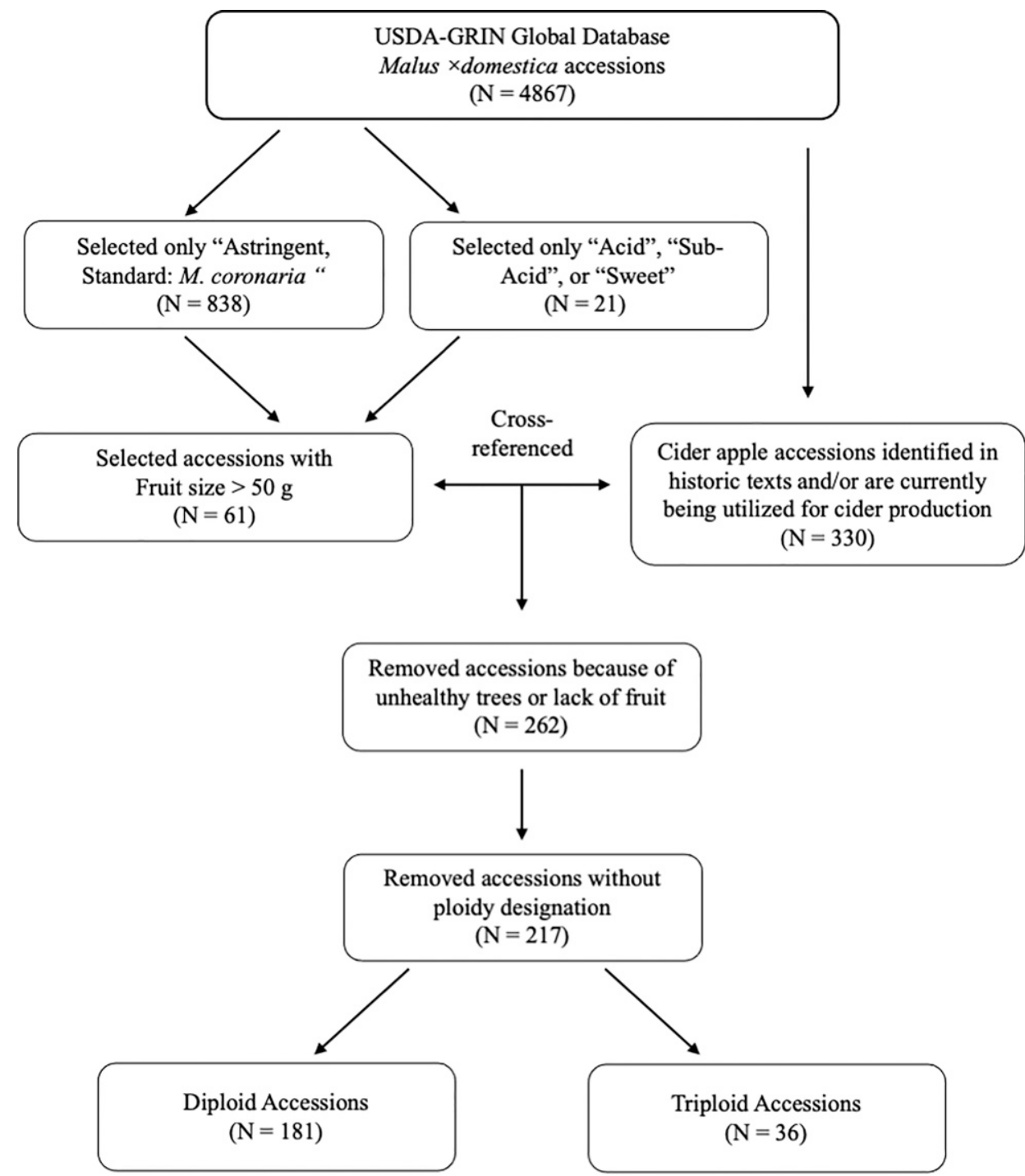

Supplemental Fig. 1. Flowchart illustrating the selection process for the cider apple accessions $(\mathrm{N}=217)$ from the U.S. Department of Agriculture Malus germplasm collection in Geneva, NY that were used in this study.
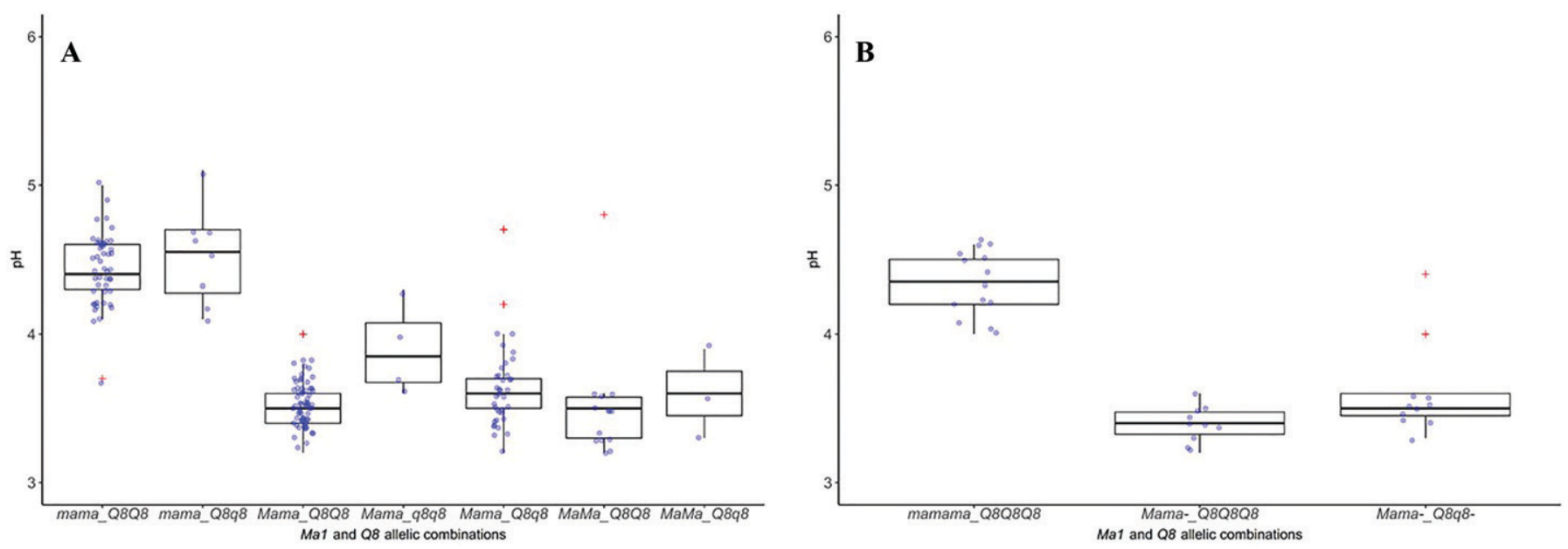

Supplemental Fig. 2. The variation in $\mathrm{pH}$ for each of the combinations of Mal and $Q 8$ alleles among $(\mathbf{A})$ diploid accessions $(\mathrm{N}=181)$ and $(\mathbf{B})$ triploid accessions $(\mathrm{N}=36)$ between 2017 and 2019 from the U.S. Department of Agriculture Malus germplasm collection in Geneva, NY. There were no mama- $q 8 q 8$ or MaMa- $q 8 q 8$ gene combinations. The blue dots represent the estimated marginal means for each accession. The red plus signs represent outliers as defined by the estimated marginal means test. 


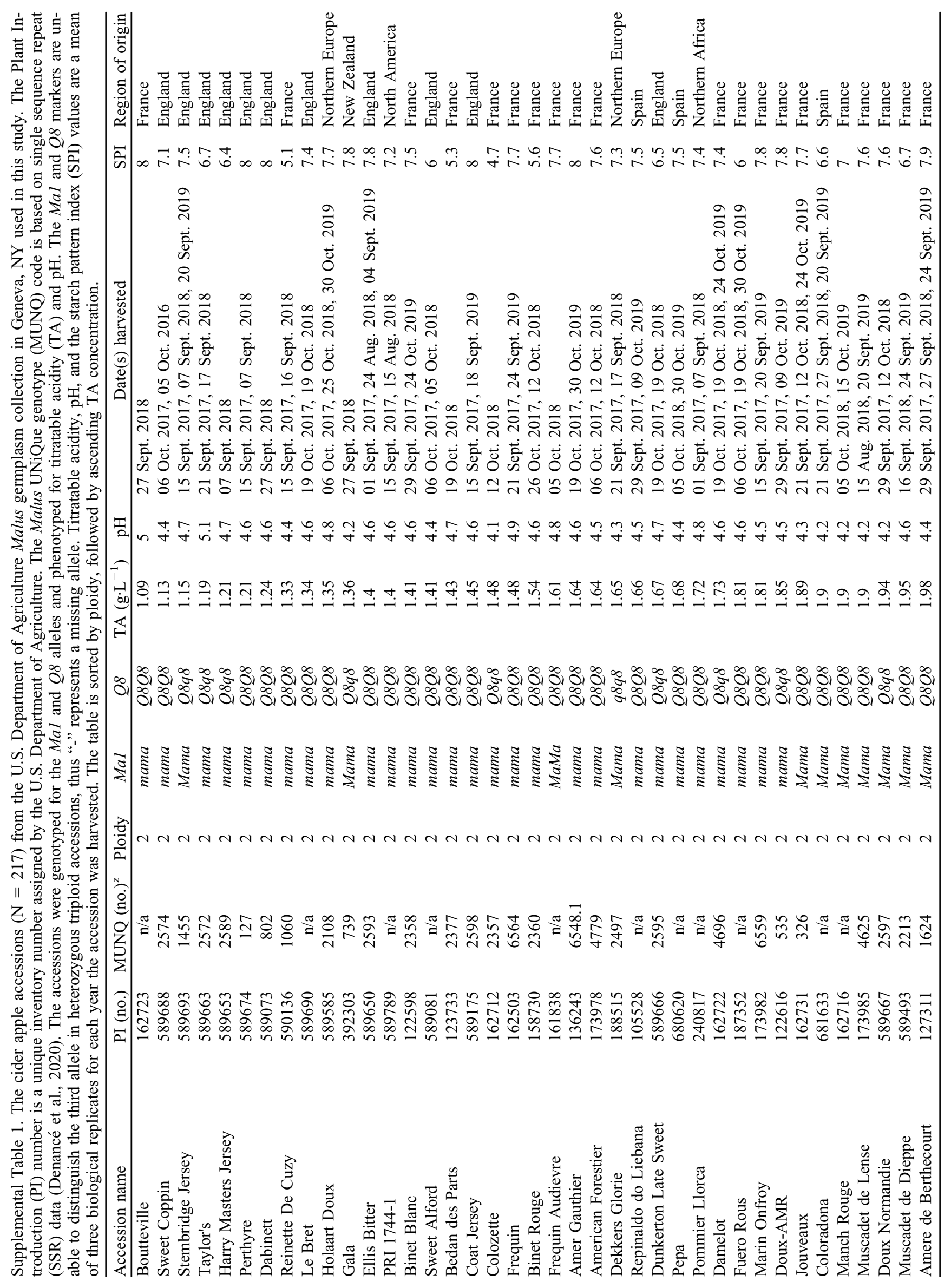




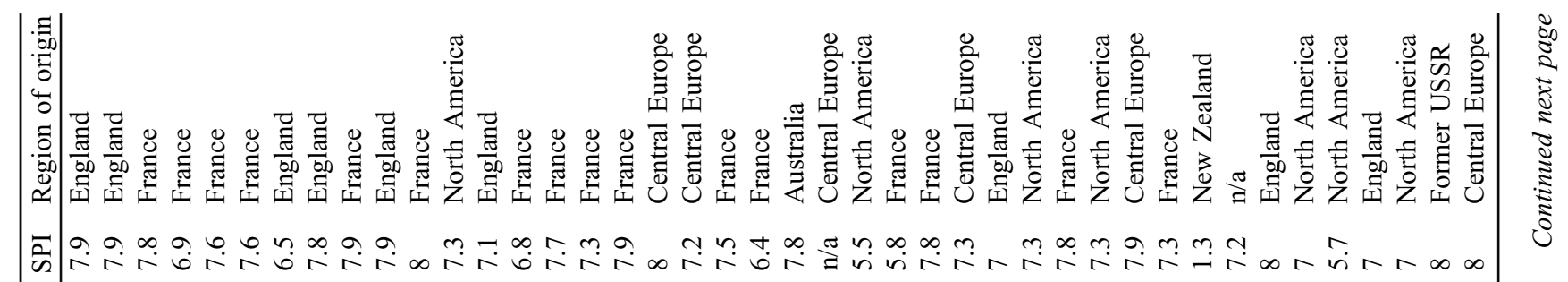

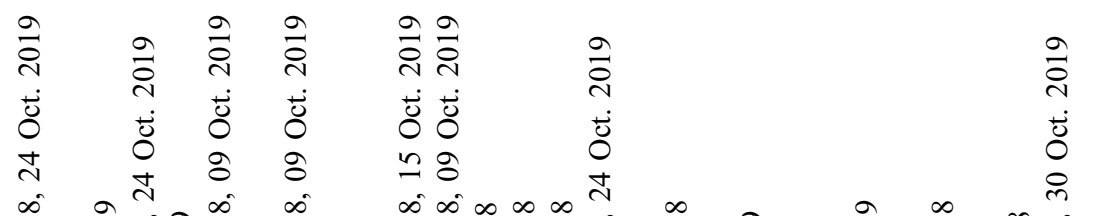

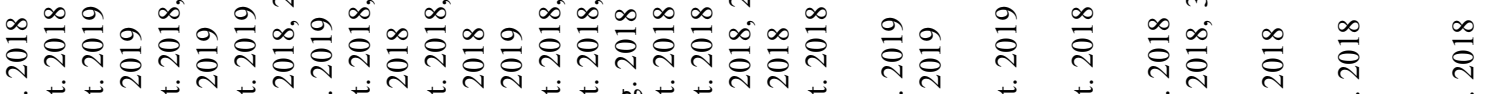

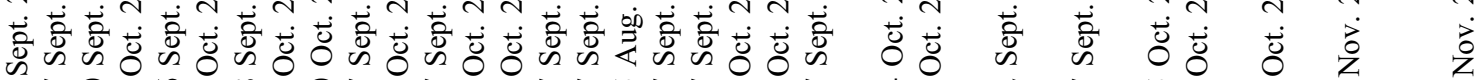

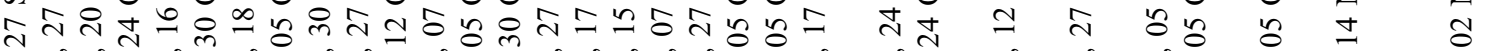

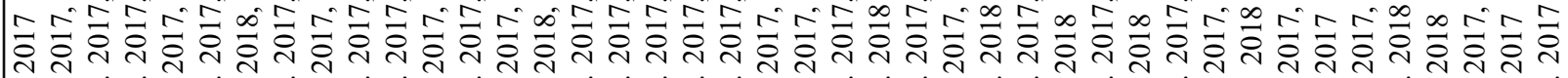

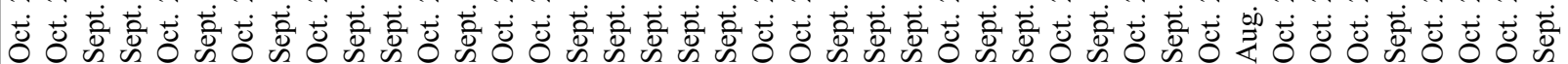
\& $\because \vec{\sim}$

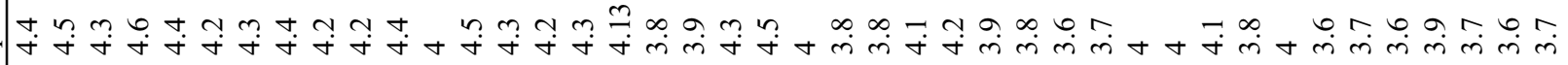

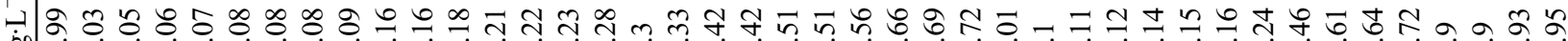

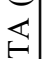

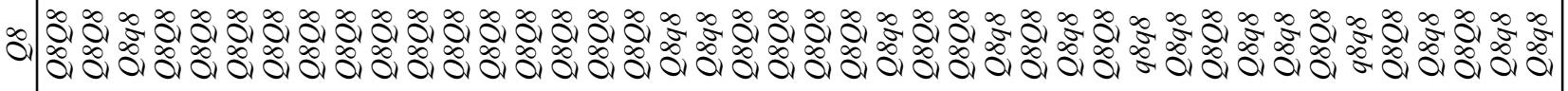

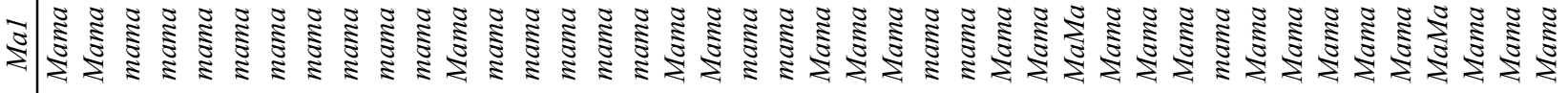

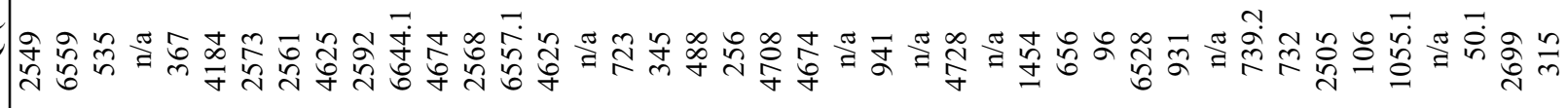

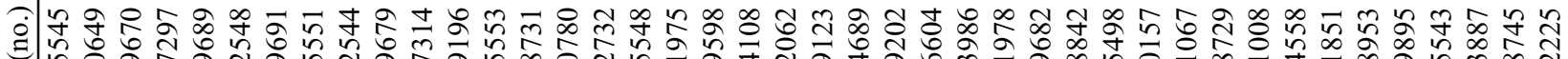

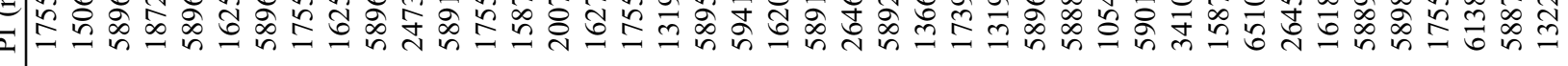




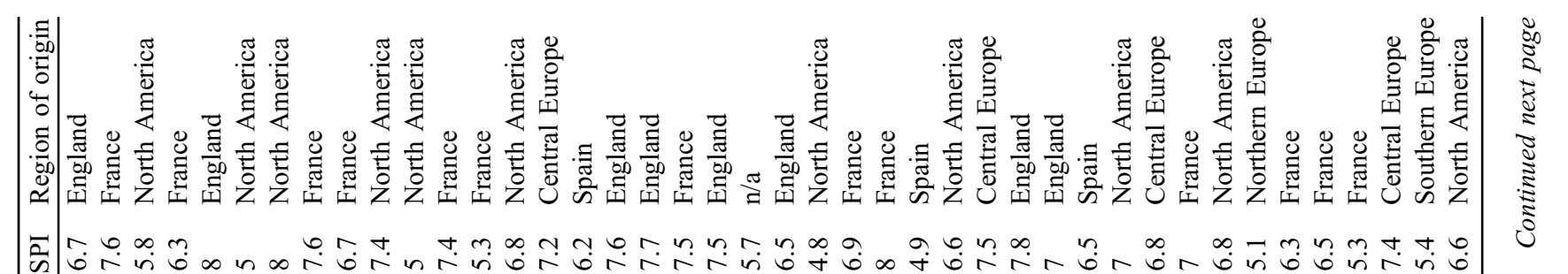

商 $\quad$ हे

$\begin{array}{llll}\dot{0} & \dot{0} & \dot{0} & \dot{0}\end{array}$

$\Xi$

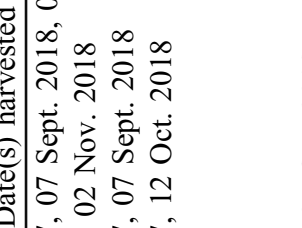

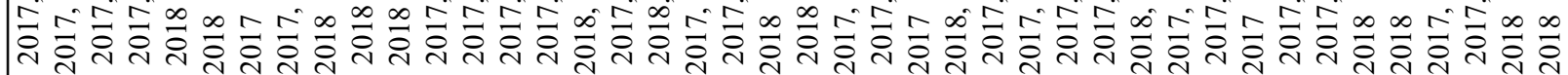

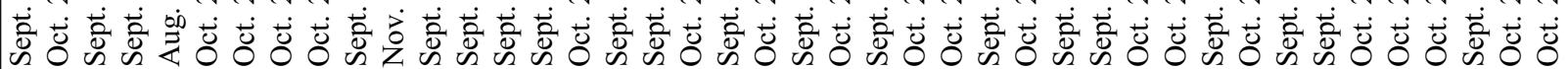

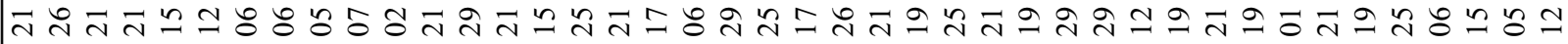

$\stackrel{\infty}{-}$

8

$\stackrel{\infty}{\infty} \stackrel{\infty}{\circ}$

$a \stackrel{\infty}{\infty} \infty$ กे

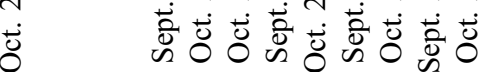

客苛

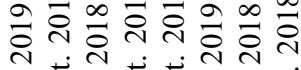

$\stackrel{\infty}{\stackrel{\infty}{\circ}}$

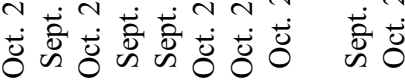

$\stackrel{\infty}{\circ} \stackrel{\infty}{\circ}$

으능ㅇㅇำ

$\widehat{\delta} \hat{\sim}$

\section{no}

ப்

9

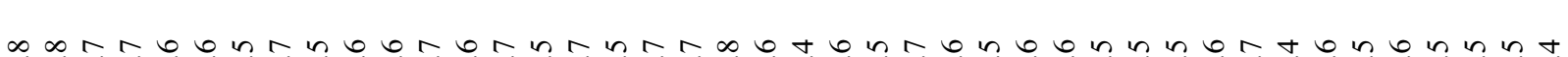

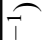

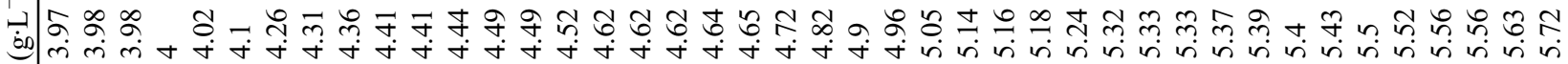

$\varangle$

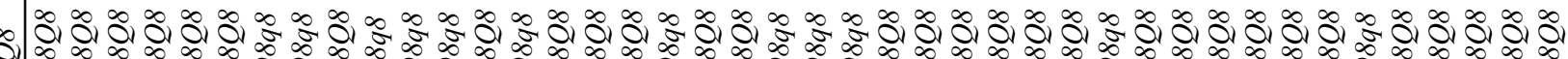

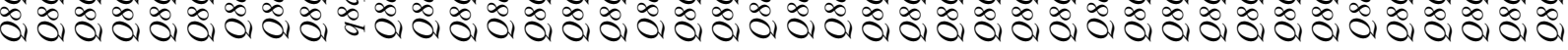

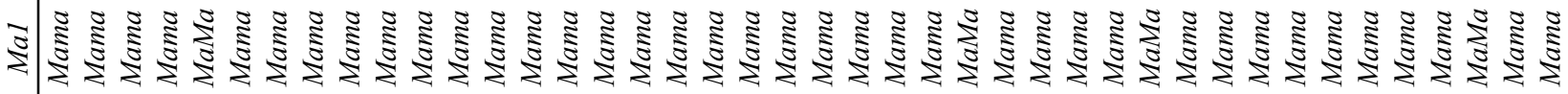

N

(1)

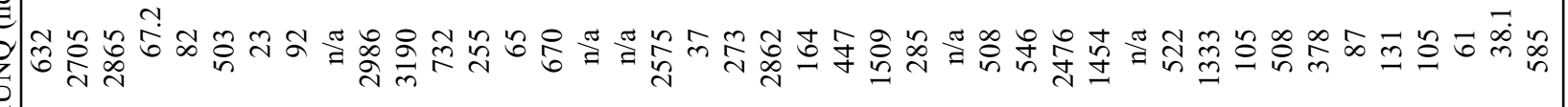



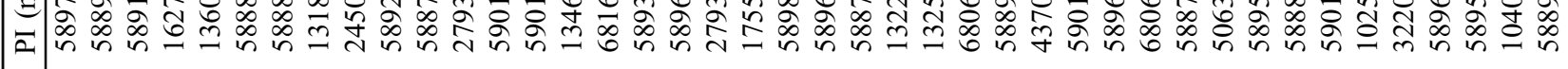

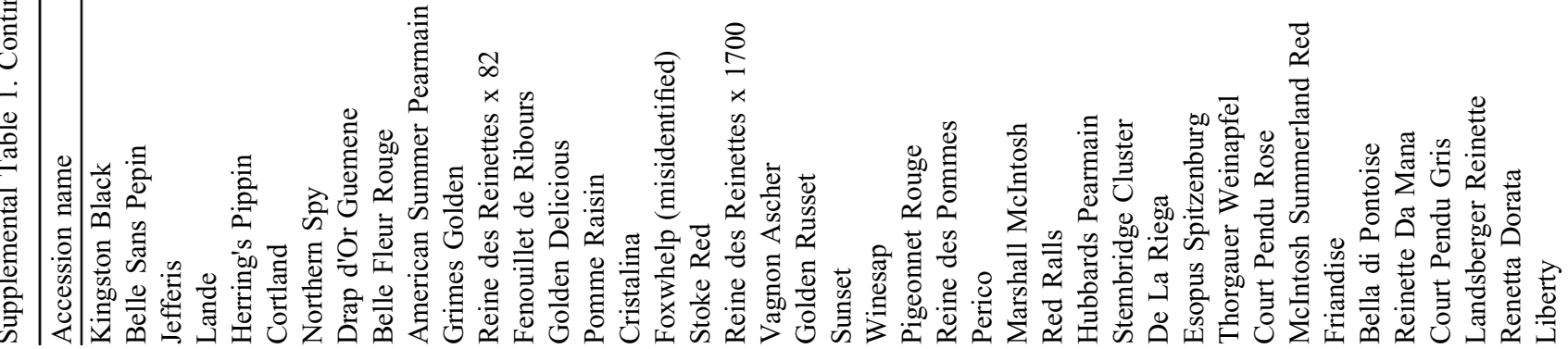




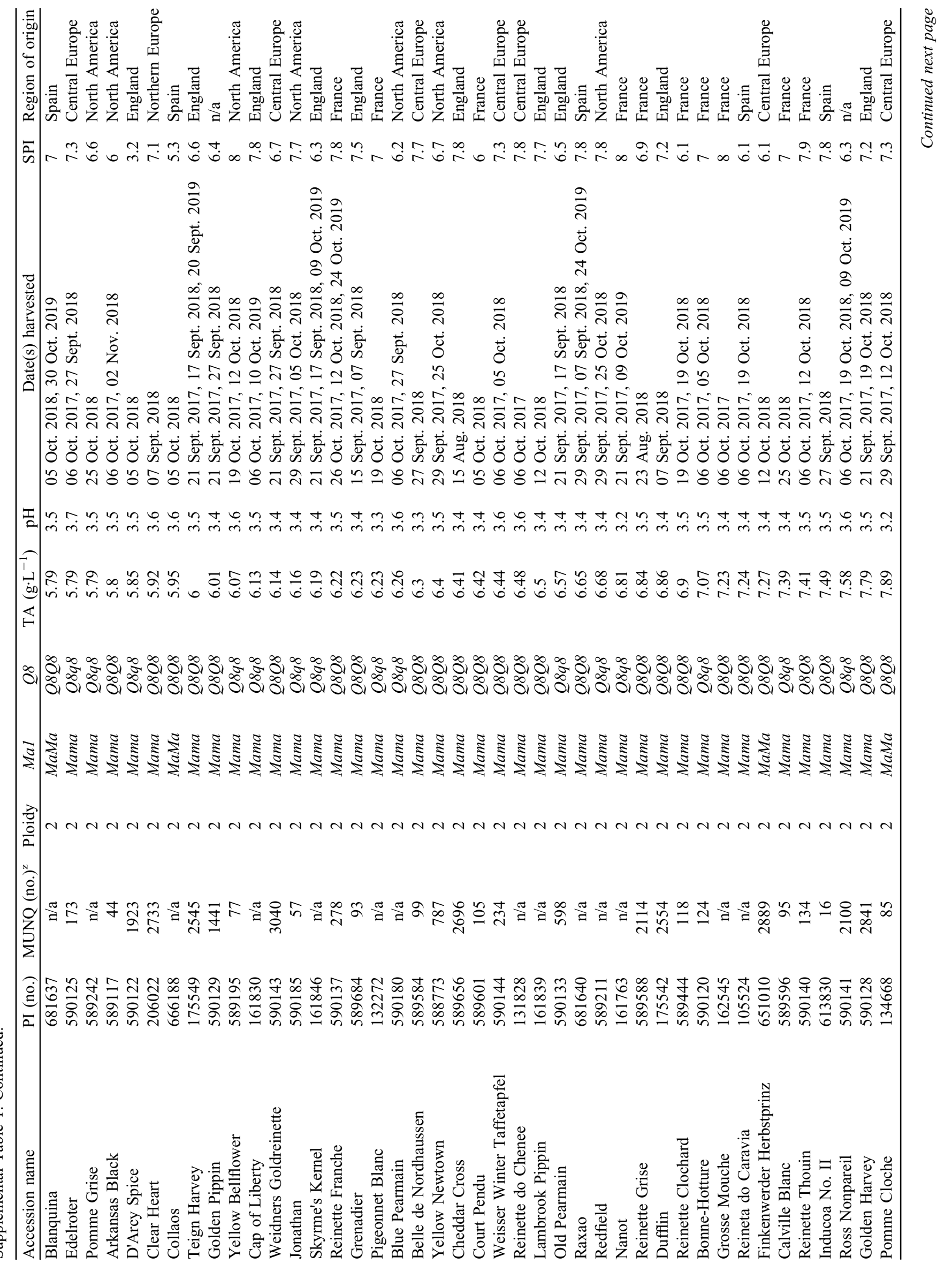




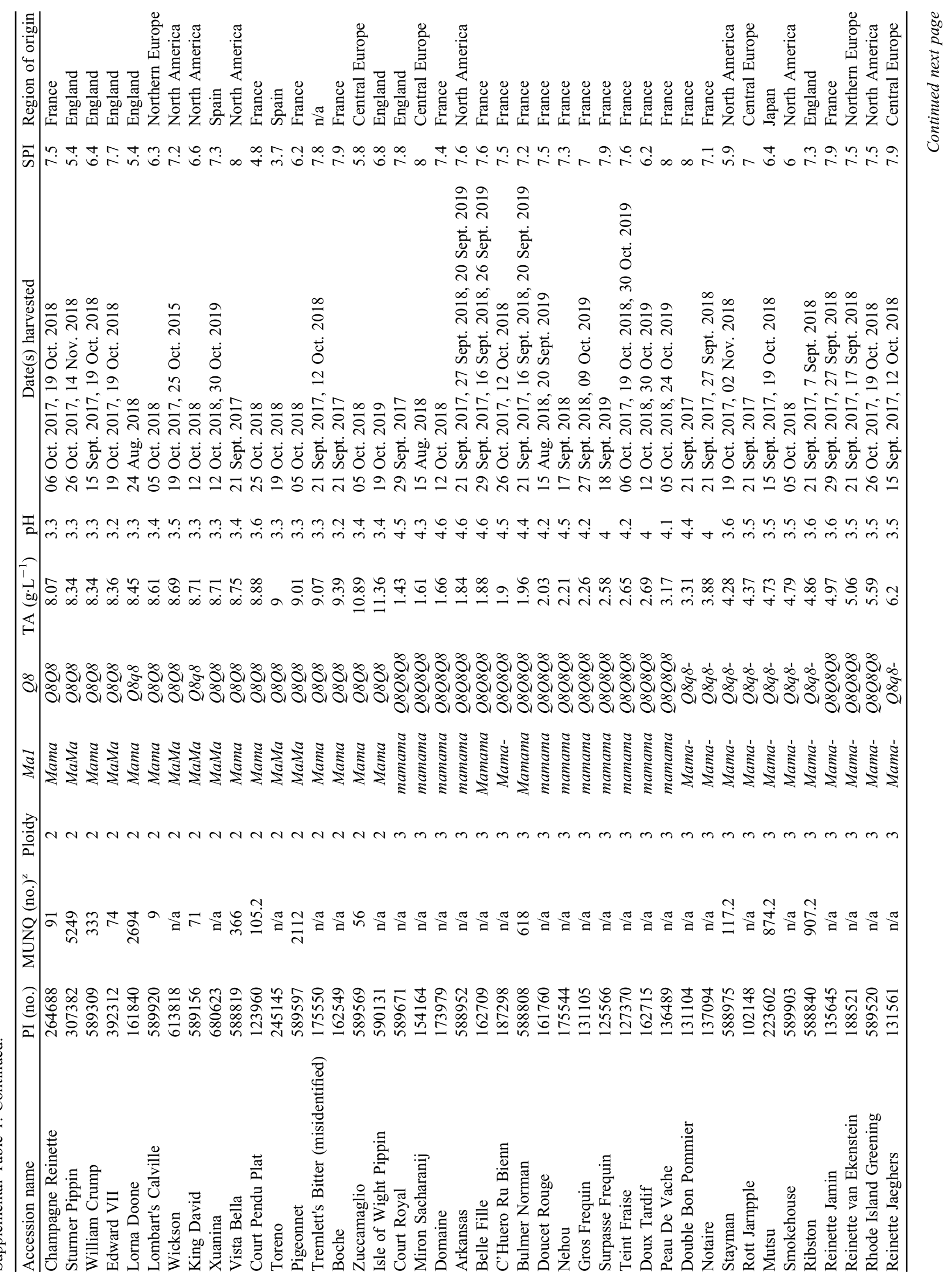




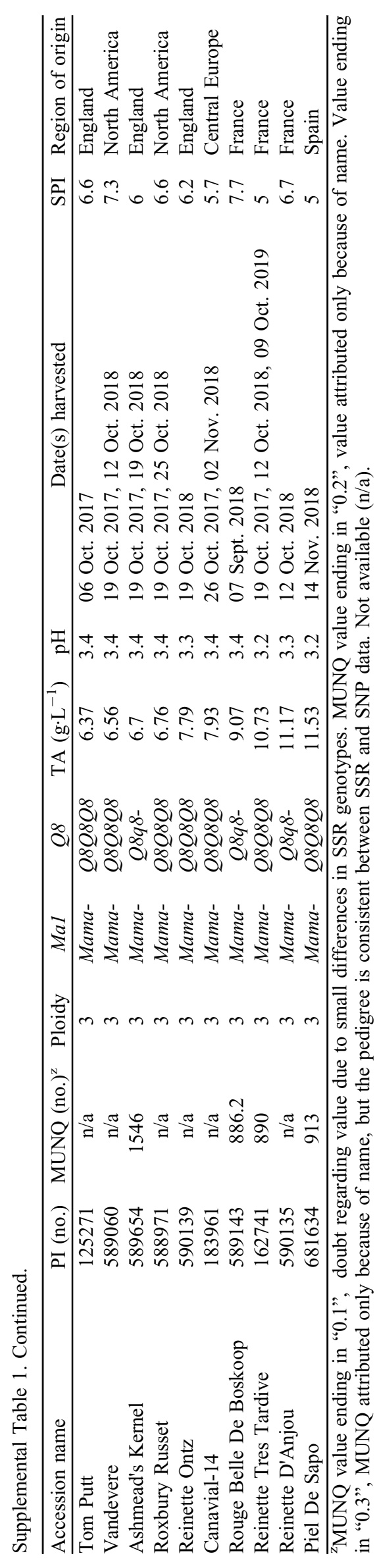

